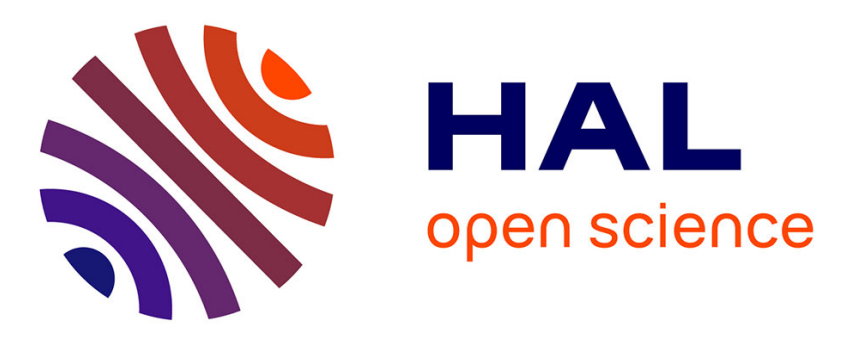

\title{
Incisor enamel microstructure of Paleogene caviomorph rodents from Contamana and Shapaja (Peruvian Amazonia)
}

Myriam Boivin, Laurent Marivaux, Rodolfo Salas-Gismondi, Emma Vieytes, Pierre-Olivier Antoine

\section{To cite this version:}

Myriam Boivin, Laurent Marivaux, Rodolfo Salas-Gismondi, Emma Vieytes, Pierre-Olivier Antoine. Incisor enamel microstructure of Paleogene caviomorph rodents from Contamana and Shapaja (Peruvian Amazonia). Journal of Mammalian Evolution, 2019, 26 (3), pp.389-406. 10.1007/s10914-0189430-4 . hal-01813140

\section{HAL Id: hal-01813140 \\ https://hal.umontpellier.fr/hal-01813140}

Submitted on 1 Nov 2020

HAL is a multi-disciplinary open access archive for the deposit and dissemination of scientific research documents, whether they are published or not. The documents may come from teaching and research institutions in France or abroad, or from public or private research centers.
L'archive ouverte pluridisciplinaire HAL, est destinée au dépôt et à la diffusion de documents scientifiques de niveau recherche, publiés ou non, émanant des établissements d'enseignement et de recherche français ou étrangers, des laboratoires publics ou privés. 
Incisor enamel microstructure of Paleogene caviomorph rodents from Contamana and Shapaja (Peruvian Amazonia)

Myriam BOIVIN $^{1}$, Laurent MARIVAUX ${ }^{1}$, Rodolfo SALAS-GISMONDI ${ }^{2}$, Emma C. $^{2}$ VIEYTES $^{3}$ and Pierre-Olivier ANTOINE ${ }^{1}$

${ }^{1}$ Laboratoire de Paléontologie, Institut des Sciences de l'Évolution de Montpellier, c.c. 064, Université de Montpellier, CNRS, IRD, EPHE, place Eugène Bataillon, F-34095 Montpellier Cedex 05, France; e-mails: myriam.boivin@umontpellier.fr, pierreolivier.antoine@umontpellier.fr, laurent.marivaux@umontpellier.fr ${ }^{2}$ Departamento de Paleontología de Vertebrados, Museo de Historia Natural - Universidad Nacional Mayor San Marcos (MUSM), Av. Arenales 1256, Lima 11, Peru; e-mail: rsalasgismondi@gmail.com

${ }^{3}$ División Zoología Vertebrados, Facultad de Ciencias Naturales y Museo, UNLP, Paseo del Bosque s/n, 1900 La Plata, Argentina; CONICET. e-mail: cvieytes@ fcnym.unlp.edu.ar 


\begin{abstract}
We investigate the enamel microstructure of 37 isolated rodent incisors from several late middle Eocene and late Oligocene localities of Contamana (Loreto Department, Peruvian Amazonia), and from the early Oligocene TAR-01 locality (Shapaja, San Martín Department, Peruvian Amazonia). All incisors show an enamel internal portion with multiserial HunterSchreger Bands (HSB). The late middle Eocene localities of Contamana yield incisors with subtypes 1, 1-2, and 2 of multiserial HSB; TAR-01 yielded incisors with 1-2, 2, 2-3, and 3 of multiserial HSB; and the late Oligocene localities of Contamana, incisors with subtypes 1-2, 2, and 2-3 of multiserial HSB. Based on our current knowledge of the South American and African rodent fossil records and given the primitiveness of the Eocene caviomorph faunas, it may be expected that the hystricognath pioneer(s) who have colonized South America from Africa sometime during the middle Eocene, most probably had incisors that displayed a multiserial enamel with an interprismatic matrix arrangement characterizing the subtype 1 (or subtype $1+$ the subtype 2 and/or the transitional 1-2) of multiserial HSB. In contrast, the derived subtypes 2-3 and 3 conditions were subsequently achieved but likely rapidly, as evidenced by its record as early as the ?late Eocene/early Oligocene (e.g., Santa Rosa, Shapaja, and La Cantera), and seemingly evolved iteratively but only in the Octodontoidea clade.
\end{abstract}

Keywords Caviomorpha, multiserial enamel, Hunter-Schreger Bands, South America, Peru, Eocene, Oligocene. 


\section{Introduction}

The study of enamel microstructure has long been practiced, the first accurate works about this dental tissue dating from the late $18^{\text {th }}$ to the early $19^{\text {th }}$ centuries (e.g., Hunter 1771 ; Schreger 1800). As enamel is one of the most mineralized and hardest tissues in vertebrates, it is resistant and as such often preserved during fossilization process (Koenigswald et al. 1993; Boyde 1997). Thanks to these characteristics, study of enamel microstructure is therefore possible in fossil teeth. These enamel investigations have contributed to provide useful characters for mammal systematics and phylogenic reconstructions (e.g., Rensberger and Koenigswald 1980), notably in rodents (e.g., Korvenkontio 1934; Koenigswald 1980, 1985; Martin 1992, 1993, 1997; Marivaux et al. 2004). In mammals, enamel is composed of prisms, which are bundles of hydroxyapatite crystallites with the same orientation. Between the prisms, there is an enamel fraction also formed by parallelly-oriented hydroxyapatite crystallites, but that are not bundled into prisms. This fraction is termed interprismatic matrix (IPM). Two main prismatic enamel types are commonly distinguished: enamel with paralleloriented and non-decussating prisms, and enamel with decussating prisms. These prism groups form layers in bands named Hunter-Schreger bands (HSB). Different enamel types often coexist in a same tooth, defining the schmelzmuster (Koenigswald 1980). In rodent incisors, the enamel is primarily formed by two layers, the Portio interna (PI), which includes the HSB, and the Portio externa (PE), which consists of radial enamel (Korvenkontio 1934). Three major types of HSB can be distinguished in rodent incisors, which were originally defined based on the number of prisms per HSB in the PI: uniserial -one prism wide-, pauciserial -two to six prisms wide (on average three)-, and multiserial -three to seven prism wide- (Korvenkontio 1934; Martin 1993). These three types roughly characterize major groups of rodents (e.g., Martin 1992, 1993, 1995, 2007; Kalthoff 2000, 2006; Marivaux et al. 
2004). Owing to a wide overlap of the number of prisms between pauciserial and multiserial

HSB, Martin $(1992,1993)$ defined new characters (e.g., configuration of the IPM with respect to the prisms, presence/absence of HSB transitional zones, inclination of HSB...) for clearly distinguishing the two types. Multiserial HSB was originally interpreted as a plesiomorphic condition, while the pauciserial and uniserial types counted as derived stages (Korvenkontio 1934; Koenigswald 1980, 1985). However, in studying a wide array of basal fossil rodents, Martin $(1992,1993)$ has demonstrated that the presence of pauciserial HSB is the most primitive condition, inasmuch as it is only found in early diverging fossil taxa. Concerning multiserial HSB, Martin (1992, 1993) distinguished three subtypes (considered here as subtypes 1,2, and 3), on the basis of the angle of the IPM crystallites with respect to the prism long axes. In the subtype 1, IPM crystallites run parallel to those of the prisms, or they form a very low angle with them, but they do not surround totally each prism (thin and sheath-like IPM). In the subtype 2, they form an acute angle and anastomose regularly, whereas in the subtype 3, the IPM shows a few or no anastomoses, and its crystallites run at a right angle to those of the prisms, forming interrow sheets (plate-like IPM). From a biomechanical viewpoint, an increasing angulation of the IPM is considered as strengthening the enamel in all three dimensions (e.g., Martin 1992, 1993, 1994a,b, 1997). On the basis of this biomechanical consideration and the stratigraphic occurrences of taxa, the enamel characterized by multiserial HSB with rectangular IPM (subtype 3) is considered to be the most specialized and derived multiserial condition (Martin 1992, 1993, 1994a,b, 1997). Accordingly, considering the IPM arrangement, the subtype 1 would be the most primitive condition of multiserial HSB, and the subtype 2 would be intermediate, between the subtypes 1 and 3 (Martin 1993, 1994a). Within hystricognathous rodents, among caviomorphs, the subtype 3 primarily characterizes most octodontoids, with the exception of sub-fossil "heptaxodontids" (but see e.g., Wood 1959; Wood and Patterson 1959; Pascual et al. 1990 
regarding the superfamilial assignation of this family), and the extinct Sallamys, Caviocricetus, Protadelphomys, Willidewu, and Plesiacarechimys (see below). The "heptaxodontid" octodontoids (giant hutias) from the Caribbean islands display incisor enamel with multiserial HSB of subtype 2 (Martin 1992). In other caviomorph superfamilies, the IPM runs with an acute angle (subtype 2) or parallel (subtype 1) to the prisms (Martin 1992, 1993). However, distinction of subtypes is not always clear. Indeed, transitional subtypes (corresponding to the presence of two subtypes) can be found among caviomorphs, but also in other hystricognath groups (e.g., Bathyergidae and Thryonomyidae; Martin 1992). There is often a difference in the IPM orientation between upper and lower incisors, the latter being usually characterized by the most derived subtypes (Martin 1994a; Vucetich and Vieytes 2006). Among caviomorphs, some extinct and extant erethizontoids (Steiromys, Chaetomys subspinosus, Coendou prehensilis, and Erethizon dorsatum) can show a transitional subtype 1-2 (Martin 1994a). This transitional subtype is also present in some incisors of early caviomorphs found at Santa Rosa (Peru, ?late Eocene/early Oligocene; Martin 2004, 2005) and La Cantera (Argentina, early Oligocene; Vucetich et al. 2010). A transitional subtype 2-3 has been also mentioned in Sallamys (Bolivia and Peru, late Oligocene; Martin 1994a), Caviocricetus lucasi (Argentina, early Miocene; Vieytes 2003; Vucetich et al. 2010, 2015; Arnal et al. 2014), Plesiacarechimys koenigwaldi (Argentina, middle Miocene; Vucetich and Vieytes 2006), Protadelphomys (Argentina, early Miocene; Vieytes 2003; Vucetich et al. 2010, 2015), Willidewu (Argentina, early Miocene; Vieytes 2003; Vucetich et al. 2015), and on some indeterminate incisors from La Cantera (Argentina, early Oligocene; Vucetich et al. 2010). In this transitional subtype 2-3, the angle between the IPM and the prisms can reach $90^{\circ}$ but only in some portions of the lower incisors (between $60^{\circ}$ and $90^{\circ}$ ), and it is comprised between $45^{\circ}$ and $70^{\circ}$ in the upper incisors (Vucetich et al. 2010). Accordingly, the transitional subtype 2-3 was interpreted by Vucetich and Vieytes 
(2006) as more primitive than the subtype 3. However, Arnal et al. (2014), based on a

phylogenetic topology, have shown that the evolution of this character could be more complicated within caviomorphs. Indeed, they proposed that the transitional subtype 2-3 might be a plesiomorphic condition from which the subtype 2 and 3 would have been both derived. Besides, owing to the divergence of Caviocricetus lucasi and Plesiacarechimys koenigwaldi within their phylogeny of octodontoids, Arnal et al. (2014) hypothesized that the transitional subtype $2-3$ of both taxa would correspond to a reversion from the subtype 3 . However, these results may also be linked to lacking data (i.e., missing lineages), because a case of reversion seems difficult to conceive inasmuch as the selective pressure is towards strengthening the enamel of the highly stressed incisor. Therefore, considering this biomechanical constraint, the alternative hypothesis considering an iterative acquisition (i.e., convergent) of the subtype 3 from subtype $2-3$, seems here to be more conceivable (Martin, Jan. 2017 com. pers., that we follow).

For several decades, our knowledge of the caviomorph Paleogene record had been limited to late Oligocene forms (i.e., Deseadan South American Land Mammal Age [SALMA]; Loomis 1914; Wood 1949; Wood and Patterson 1959; Patterson and Pascual 1968; Hoffstetter and Lavocat 1970; Hartenberger 1975; Lavocat 1976; Mones and Castiglioni 1979; Patterson and Wood 1982; Hartenberger et al. 1984; Vucetich 1989). It was only from the 1990s that several pre-Deseadan rodent faunas were discovered: Termas del Flaco (Tinguirirican SALMA; Wyss et al. 1993; Bertrand et al. 2012), Santa Rosa (Frailey and Campbell 2004) and La Cantera (Vucetich et al. 2010). One locality in the West Indies (west bank of Río Guatemala at Puerto Rico, Greater Antilles; early Oligocene) has yielded only one caviomorph incisor, the enamel of which displays the subtype 2 of multiserial HSB (Vélez-Juarbe et al. 2014). Recently, new Paleogene localities were found at Contamana (Loreto Department) and Shapaja (San Martín Department) in Peruvian Amazonia (Antoine et 
al. 2012, 2016, 2017; Boivin et al. 2017a, 2017b, in press). Some of the Contamana localities (CTA-47, CTA-51, CTA-27, CTA-73, CTA-66, and CTA-29) have yielded the oldest known caviomorph assemblages from South America (late middle Eocene, Barrancan SALMA; Antoine et al. 2012, 2016, 2017; Boivin et al. 2017a). Regarding pre-Deseadan localities of South America, only incisor specimens from Santa Rosa (SR) and La Cantera (LC) have been subject to detailed analyses of the enamel microstructure (SR: Martin 2004, 2005; LC:

Vucetich et al. 2010). The incisor enamel microstructure of the earliest known caviomorphs from CTA-27 was also briefly mentioned (multiserial subtype 1 to 2 ) but without detailed description and figuration (Antoine et al. 2012, p. 1321).

The present work provides an exhaustive analysis (description and figuration) of the enamel microstructure of incisors recovered at CTA-27, as well as those from other Paleogene localities of Contamana and Shapaja. This study contributes to further our understanding of the early evolutionary history of the enamel microstructure within caviomorphs.

\section{Material and Methods}

The material of this study corresponds to isolated fragments of caviomorph incisors from several Paleogene localities of Contamana (late middle Eocene: CTA-47, CTA-27, CTA-29; late Oligocene: CTA-32, CTA-61; Antoine et al. 2012, 2016, 2017; Boivin et al. 2017a., 2017b) and Shapaja (early Oligocene: TAR-01; Klaus et al. 2017; Boivin et al. in press) in Peruvian Amazonia. The taxonomic content of each studied locality is provided in Table 1. Unfortunately, we have no formal taxonomical identification of these incisors, because they were collected, as for molars and premolars, after wet screening ( $1 \mathrm{~mm}$ mesh $)$ of the sediments (i.e., each tooth is an isolated specimen). We have used a criterion of size 
compatibility between incisors and molars for orienting our assessment regarding taxonomic identification of incisors, but the latter remains only tentative. Of the hundreds of incisor fragments recovered in the Paleogene localities of Contamana, we have selected 25 specimens for enamel microstructure analyses (two at CTA-47, 15 at CTA-27, one at CTA-29, one at CTA-32, and six at CTA-61; Tables 2-3). Twelve incisor fragments from TAR-01 were chosen over the $\sim 650$ dental specimens found at Shapaja (Table 4). For the analyses, we have selected well-preserved upper and lower incisor fragments of different sizes (Table 2-4).

We have measured the anteroposterior width of each studied incisor (Table 2-4), then followed the protocol of Tabuce et al. (2007) for sample preparation. All specimens were embedded in epoxy resin and polished longitudinally. We subsequently performed $37 \%$ phosphoric acid etching of the samples 30 seconds to make microstructural details visible. After rinsing with distilled water and drying, samples were coated with conductive material (gold-palladium). They were observed and studied with two different scanning electron microscopes (SEM): HITACHI S 4000 and HITACHI S 4800. The datasets (SEM photographs) generated and analyzed during the current study are available from the corresponding author on reasonable request. In contrast, all prepared and analyzed specimens are permanently housed in the paleontological collections of the Museo de Historia Natural of the Universidad Nacional Mayor de San Marcos (MUSM) in Lima, Peru.

The nomenclature corresponding to enamel microstructure follows that of Koenigswald and Sander (1997) and Martin (1992, 1993). Many standard measures were realized (Tables 2-4) following Martin (1992). For enamel thickness, inclination of prisms in PE and inclination of HSB, ten repeated measures were made for each variable. The inclination of HSB corresponds to the angle between the HSB direction and the perpendicular to the EDJ plan (see Martin 2004: fig. 1). The angle between the IPM crystallites and the prism crystallites was measured at the level of the HSB, where the prism axis is the longest. 
For an incisor, the identification of a subtype of multiserial HSB was based on the observation of the whole longitudinal section available of the specimen. However, it must be noted that the distinction between the main subtypes $(1,2$, and 3$)$, notably the transitional ones (1-2 and 2-3) is somewhat subtle, and as such sometimes arbitrary, especially between the subtype 3 and the transitional 2-3.

\section{Results}

All studied specimens present a configuration of the enamel microstructure typical of hystricognathous rodents: the enamel layer is divided into an external portion (PE) constituted of radial enamel and an internal portion (PI), thicker and essentially composed of multiserial HSB.

\section{Contamana}

CTA-47, late middle Eocene (Table 2)

The enamel microstructure was studied in two incisor fragments from CTA-47 (MUSM 2649 and 2650), the earliest rodent-yielding locality of the Contamana section. For both incisors, the transitional zone is well developed and the prism cross sections are flattened in PI.

The MUSM 2649 incisor is particularly damaged and likely exhibits numerous marks of digestion (corrosion due to etching by gastric fluids of a predator). Indeed, its enamel lacks PE (seemingly removed) and as such limited to PI. In this layer, the HSB are inclined by $36^{\circ}$, and each comprises two to three prisms. The IPM crystallites, arranged as thin sheets, 
anastomose frequently and form acute angles with the prism crystallites $\left(\sim 30^{\circ}\right)$, thereby typifying a subtype 2 of multiserial HSB.

The MUSM 2650 incisor has a total enamel thickness (PI + PE) of $155 \mu \mathrm{m}$, with PE representing 16\%. As in MUSM 2649, the IPM crystallites in PI form acute angles of $\sim 30^{\circ}$ with the prism crystallites. However, MUSM 2650 rather displays a transitional subtype 1-2 [i.e., subtype (1)-2; Table 2], with sheath-like/sheet-like IPM. Indeed, the anastomoses of the IPM crystallites are very frequent. In PI, the HSB display two to four prisms and are inclined by $23^{\circ}$. In PE, prisms are inclined by $69^{\circ}$.

CTA-27, late middle Eocene (Table 3)

The investigated sample of that locality comprised 14 incisor fragments: seven documenting lower incisors, six documenting upper incisors, and one of indeterminate attribution. In this sample, there is a noticeable disparity in the size of the incisors, but that is rather continuous, ranging from 0.6 to $1.4 \mathrm{~mm}$. The width of these incisor fragments is clearly smaller than that of the cheek teeth of Cachiyacuy contamanensis and Eobranisamys javierpradoi, but compatible to that of the teeth of Cachiyacuy kummeli, Canaanimys maquiensis, and Eoespina sp. (Antoine et al. 2012; Boivin et al. 2017a). The smallest incisors (MUSM 2814, 2815,2816 , and 2817) might belong to juveniles of these taxa, or to species so far not documented by cheek teeth.

One upper incisor (MUSM 2803; Fig. 1a-b) has a very peculiar IPM arrangement, which recalls to some extent that found in the primitive pauciserial enamel condition. Indeed, in this sample the IPM crystallites anastomose very frequently and regularly, and tend to surround each prism. The IPM crystallites run parallel to the prism direction or with a low angle (up to $20^{\circ}$ ). Transitional zones are scarce and faintly visible. Finally, the HSB are only 
slightly inclined $\left(15^{\circ}\right)$. However, compared with the pauciserial condition, this enamel microstructure is clearly distinct in having flattened prisms, a thinner IPM that does not completely surround prisms in PI, and a relatively thicker total enamel layer (181 $\mu \mathrm{m}$, superior to the inferior limit of the multiserial, i.e., $140 \mu \mathrm{m}$; Martin 1994b: table 1). There are three to four prisms per HSB. The PE composes $17-26 \%$ of the entire enamel thickness. Given these observations, the enamel condition of this incisor corresponds therefore to the subtype 1 of multiserial HSB.

One lower incisor (MUSM 2817) has a transitional subtype 1-2 of multiserial HSB [i.e., subtype 1-(2); Table 3]. The IPM appears as a moderately thin sheet, which anastomoses very frequently, and the IPM crystallites run parallel or at a low-medium angle to the prism direction $\left(35^{\circ}\right)$. This multiserial enamel subtype recalls the pauciserial condition, notably in the relatively low inclination of the HSB in PI $\left(26^{\circ}\right)$, and in the rather thin total enamel layer $(93 \mu \mathrm{m})$. However, this multiserial enamel subtype is distinct from the pauciserial condition, notably in the presence of flattened prisms, a thinner IPM that does not (or very rarely) completely surround prisms in PI, the presence of transitional zones between HSB, and in showing a strong inclination of the prisms in PE $\left(85^{\circ}\right)$. The HSB have three to four prisms. The PE composes $18-25 \%$ of the entire enamel thickness.

Most other incisors from this locality (seven lower, five upper, and one indeterminate) exhibit the subtype 2 of multiserial HSB, which is characterized by sheet-like IPM, and IPM crystallites that form acute angles with the prism crystallites. Although sometimes elevated (up to $79^{\circ}$ ), the average angles between crystallites of IPM and prisms of these incisors range from $40^{\circ}$ to $65^{\circ}$. Anastomoses of IPM sheets are rare in most of the incisors, but they can be frequent (MUSM 2805, 2806, and 2811) or very frequent (MUSM 2813) in some cases. The transitional zones are well developed, except for three specimens (MUSM 2807, 2804, and 2816). In most cases, the HSB comprise four prisms, but punctually, two to five prisms per 
band can be observed. In all incisors, prisms in PI are flattened in cross section. In PI, HSB are inclined from $22^{\circ}$ to $45^{\circ}$, and in PE, prisms are inclined from $55^{\circ}$ to $85^{\circ}$. Total enamel thickness is very variable, but it always exceeds $100 \mu \mathrm{m}$ (averages ranging from 115 to 246 $\mu \mathrm{m})$. The PE composes $17-23 \%$ of the total enamel thickness. MUSM 2805 tends to develop a thin prismless external layer (PLEX).

CTA-29, late middle Eocene (Table 2)

The only studied specimen from CTA-29 (lower incisor, MUSM 2840; Fig. 2a-b) displays the subtype 2 of multiserial HSB, characterized by HSB with sheet-like IPM and IPM crystallites forming acute angles with the direction of the prism crystallites (from $32^{\circ}$ to $58^{\circ}$ ). Anastomoses of the IPM are rare and transitional zones between two adjacent HSB are well marked. The HSB have between two and four prisms. The prism cross sections are flattened or round in PI. The HSB are inclined by $33^{\circ}$ in PI and prisms by $84^{\circ}$ in PE. Total enamel thickness is about $174 \mu \mathrm{m}$, with a PE representing $20 \%$.

CTA-32, late Oligocene (Table 2)

Enamel of the lower incisor from CTA-32 (MUSM 2873) corresponds to the subtype 2 of multiserial HSB, characterized by sheet-like IPM and IPM crystallites that form acute angles with the direction of prism crystallites (between $40^{\circ}$ and $52^{\circ}$ ). Anastomoses of the IPM sheets are rare. Transitional zones between adjacent HSB are scarce, and when present, they are weakly pronounced. The HSB comprise between two and four prisms, which are flattened in cross section. In PI, HSB are inclined by $37^{\circ}$, and in PE, prisms are inclined by $74^{\circ}$. Enamel is about $88 \mu \mathrm{m}$ thick and the PE composes $27 \%$ of the total thickness. 
CTA-61, late Oligocene (Table 2)

One incisor (MUSM 2902) exhibits a transitional subtype 1-2 of multiserial HSB [i.e., subtype 1-(2); Table 2]. The PI of that enamel displays sheet-like IPM, the crystallites of which anastomose very frequently, running parallel or at a low-medium angle to the prism direction (up to $10^{\circ}$ ). This subtype of multiserial enamel somewhat recalls the pauciserial condition, notably in the IPM arrangement and in showing a relatively low inclination of the HSB $\left(23^{\circ}\right)$. However, this subtype of multiserial enamel differs specifically from the pauciserial condition in having flattened prisms, a thinner IPM that does not completely surround the prisms in PI, the presence of transitional zones between HSB, a strong inclination of the prims in $\mathrm{PE}\left(83^{\circ}\right)$, and in showing a relatively thicker total enamel layer (173 $\mu \mathrm{m}$; cf. Martin 1994b: table 1). The HSB comprise three to five prisms. The PE composes $18 \%$ of the entire enamel thickness.

Most incisors (two lower, one upper, and one indeterminate) display the subtype 2 of multiserial HSB, characterized by the presence of sheet-like IPM and with IPM crystallites that form acute angles with the direction of the prism crystallites (between $27^{\circ}$ and $60^{\circ}$ ). Anastomoses of IPM crystallites can be rare (MUSM 2904 and 2905), frequent (MUSM 2906) or absent (MUSM 2907). Transitional zones are well marked. The HSB comprise between three and four prisms, except for MUSM 2907, in which there are two to four prisms per band. In all incisors, prisms in PI are flattened in cross section. The HSB are inclined from $27^{\circ}$ to $37^{\circ}$. In MUSM 2907, prisms are less inclined in PE $\left(57^{\circ}\right)$ than in other incisors where they are inclined by $73^{\circ}$ to $80^{\circ}$. Total enamel thickness is very variable but always exceeding $100 \mu \mathrm{m}$ (between 139 and $284 \mu \mathrm{m}$ ). The PE composes 15-22\% of entire enamel thickness. 
One lower incisor (MUSM 2903; Fig. 1c-d) shows a transitional subtype 2-3 of

multiserial HSB. The angle between the orientation of the IPM crystallites and that of prism crystallites is acute, and in some cases reaches up to $85^{\circ}$ (almost right-angled). Anastomoses of the IPM are frequent. Transitional zones are well marked between two adjacent HSB. The latter comprise from three to four prisms. In PI, the HSB are strongly inclined $\left(40^{\circ}\right)$, and prisms are flattened or round in cross section. In PE, the prisms are very strongly inclined $\left(83^{\circ}\right)$. Total enamel thickness is $156 \mu \mathrm{m}$, with a PE representing $21 \%$.

\section{Shapaja (early Oligocene)}

TAR-01 (Table 4)

The investigated sample comprises seven upper and five lower incisors, which show a noticeable disparity in size, ranging from 0.6-2.6 mm (continuous range). The MUSM 3342 incisor is clearly set apart from other incisors by its larger size (width $=2.6 \mathrm{~mm}$ ), compatible with the size of cheek teeth of Eoincamys cf. E. pascuali and Shapajamys (recorded in TAR01; Boivin et al. in press), thereby suggesting that this incisor could be referred to one of these two taxa. Like in CTA-27, the smallest incisors (MUSM 3351, 3352, and 3353) might either belong to juveniles of the smallest taxa (Mayomys and Tarapotomys) or to adults of even more tiny taxa still not documented by cheek teeth.

Two subtypes of multiserial HSB are clearly identified, the subtype 2 (acute IPM) and subtype 3 (rectangular IPM), but also few transitional subtypes (1-2 and 2-3).

Two upper incisors (MUSM 3344 and 3353; Fig. 1c-d) have a transitional subtype 12 [including subtype (1)-2; Table 4] of multiserial HSB. Both specimens are characterized by frequently anastomosed sheet-like IPM and by IPM crystallites that run parallel or at a low angle to the prism crystallites (up to $40-43^{\circ}$ ). This multiserial enamel subtype is distinct from 
the pauciserial condition in showing PI bearing HSB with oval or flattened prisms, a thinner

IPM that does not (or very rarely) completely surround the prisms, the presence of transitional zones between HSB, moderately inclined HSB (23-24 $)$, and a strong inclination of the prisms in $\mathrm{PE}\left(62^{\circ}\right.$ and $\left.80^{\circ}\right)$. The HSB comprise three to four prisms. Compared with MUSM 3344, enamel microstructure of MUSM 3353 would be more similar to the pauciserial condition, notably in the noticeable strong IPM thickness, which nearly forms a sheath-like structure surrounding the prisms, and in showing a relatively thinner total enamel layer (cf. Martin 1994b: table 1).

Five incisors (three upper and two lower) have multiserial HSB with sheet-like IPM and with IPM crystallites that form acute angles with prism crystallites (subtype 2). Anastomoses of IPM sheets are rare, except for two incisors (MUSM 3350 and 3351) in which they are frequent. Transitional zones are well marked, except in one specimen (MUSM 3351). The two largest incisors (MUSM 3342 and 3345) can have up to five prisms per HSB, whereas others only display three to four prisms per band. In virtually all incisors, prism cross section is flattened in PI, except for two of them (MUSM 3342 and 3347), which can also show rounded prisms. The HSB are inclined from $17^{\circ}$ to $40^{\circ}$ in $\mathrm{PI}$, and the prisms from $63^{\circ}$ to $83^{\circ}$ in PE. Total enamel thickness varies between 111 and $176 \mu \mathrm{m}$, with PE representing 13 to 23\%. Three of the five considered incisors (MUSM 3345, 3347, and 3351) tend to develop a small prismless external layer (PLEX).

Two incisors (one lower and one upper) show a transitional subtype $2-3$ of multiserial HSB [including subtype (2)-3; Table 4]. The angle between the orientation of the IPM crystallites and that of prism crystallites is acute to rectangular, but always higher than that found in the subtype 2 of multiserial HSB. Anastomoses of IPM sheets are rare (MUSM 3343) or not observed (MUSM 3348). Transitional zones between adjacent HSB are well marked. The HSB comprise three to four prisms in MUSM 3343, and two to three prisms in 
MUSM 3348. In these two incisors, the prisms in PI are flattened in cross section. The HSB

\section{Discussion}

Bearing of incisor enamel microstructure in phylogenetic relationships of hystricognathous rodents

During the $20^{\text {th }}$ century, two main hypotheses surrounding the origin of caviomorph rodents were proposed and ardently debated. Some have advocated and long defended a North 
American origin ("Franimorpha" [Ischyromyidae and Reithroparamyidae] or Paramyidae or

Sciuravidae; Wood 1949, 1950, 1959, 1962, 1965, 1972, 1973, 1974, 1975, 1980, 1983, 1984, 1985a,b; Wood and Patterson 1959, 1970; Patterson and Wood 1982), while others have strongly defended an African origin (Thryonomyoidea, Phiomorpha; Lavocat 1969, 1971, 1973, 1974a,b, 1976, 1977a,b, 1980; Hoffstetter 1971, 1972, 1975; Hoffstetter and Lavocat 1970). On the basis of an increasing body of anatomical (e.g., Mossman and Luckett 1968; Dawson 1977; Korth 1984; Bugge 1985; Meng 1990; Luckett and Hartenberger 1993; Martin 1994b; Marivaux et al. 2002, 2004) and molecular (e.g., Nedbal et al. 1996; Huchon and Douzery 2001; Poux et al. 2006; Montgelard et al. 2008; Blanga-Kanfi et al. 2009; Churakov et al. 2010; Fabre et al. 2012) evidence, and also parasite studies (e.g., Durette-Desset 1971; Quentin 1973; Hugot 1982), the African origin of caviomorphs has gained strong support over the past two decades, and reached a well-accepted consensus. This African hypothesis has been substantially strengthened in recent years by the discovery in Peruvian Amazonia (Contamana) of very ancient fossil caviomorphs, dating from the late middle Eocene (Antoine et al. 2012), which exhibit strong morphological affinities with sub-coeval African hystricognathous rodents (i.e., stem hystricognaths and phiomorphs; see Barbière and Marivaux 2015).

In the 1990s, study of enamel microstructure has significantly contributed to substantiating the relationships between New World caviomorphs and Old World phiomorphs (Martin 1992, 1993, 1994b, 2004, 2005). Indeed, these two groups share the same incisor enamel microstructure (multiserial HSB), a condition which is also shared with ctenodactylids (gundis) and pedetids (springhares; e.g., Martin 1995; Marivaux et al. 2011). Subsequently, molecular and morpho-paleontological evidence has supported the existence of the Ctenohystrica, a clade which clusters ctenodactylids with hystricognathous rodents (phiomorphs + caviomorphs; e.g., George 1985; Huchon et al. 2000, 2002, 2007; Marivaux et 
al. 2002, 2004), thereby underscoring the derived/shared multiserial enamel condition for all

advanced stem and crown members of this clade (Martin 1994b; Marivaux et al. 2004).

Enamel microstructure was therefore a key morphological character for rejecting the hypothesis of a North American origin for caviomorphs. In fact, in being characterized by changes from the pauciserial to the uniserial condition, incisor enamel microstructure of Eocene rodents from North America (formerly involved into a possible ancestry of caviomorphs; sensu Wood) has proven to be entirely divergent from that of Ctenohystrica (e.g., Martin 1992, 1993, 1994b, Marivaux et al. 2004).

The early stages of multiserial HSB (subtypes 1, 1-2, and 2) in caviomorph incisors

Incisors of extinct or extant caviomorphs display a multiserial enamel microstructure, but with different degrees of IPM arrangement (i.e., presence of additive derived subtypes 1, 2, 3, including transitional stages 1-2 and 2-3; e.g., Martin 1992, 1993, 1994a, 2004, 2005; Vieytes, 2003; Vucetich and Vieytes 2006; Vucetich et al. 2010; Supplementary Table S1). The same is true for African hystricognaths, which display similar but convergent derived subtypes of multiserial HSB, as those observed in caviomorphs (Martin 1992, 1993, 1994b; Coster et al. 2010; Marivaux et al. 2012, 2014; Supplementary Table S1). Until recently, the incisor enamel microstructure of early caviomorphs was only documented by fossils dating from the Oligocene (La Cantera and Salla; e.g., Martin 1992; 1993; Vucetich et al. 2010; Supplementary Table S1) and from the ?latest Eocene/early Oligocene (Santa Rosa; Martin 2004, 2005). In analyzing enamel microstructure of incisors recovered from Contamana and Shapaja (in addition to the preliminary analysis mentioned but not figured in Antoine et al. 2012:1321), we then provide here new data regarding microstructural enamel pattern of 
Oligocene forms, but also that of late middle Eocene forms, which represent the oldest

It is worth noting that based on the set of incisor fragments analyzed from Contamana or Shapaja, no specimen displays the pauciserial condition characterizing the primitive enamel microstructure found in basal rodents (e.g., Martin 1993; Marivaux et al. 2004), notably in early ctenodactyloids, the group in which Ctenodactylidae and Hystricognathi are nested within (e.g., Marivaux et al. 2002, 2004). Nor are there incisors displaying an enamel transitional from the pauciserial to the multiserial condition. The most primitive subtype, the subtype 1 of multiserial HSB, is documented only for one incisor from CTA-27 (MUSM 2803; Fig. 1a-b). However, two other specimens, MUSM 2817 (lower incisor) and 2902 (indeterminate incisor) from CTA-27 and CTA-61, respectively, show a rather primitive enamel type close to the subtype 1 [i.e., transitional subtype 1-(2); the subtype 2 being dominant in both localities; see Tables 2-3 and discussion below]. CTA-27, late middle Eocene in age, record the most ancient and primitive caviomorphs (i.e., stem Caviomorpha: Cachiyacuy and Canaanimys; Table 1) to be known in South America (Antoine et al. 2016; Boivin et al. 2017a). Given that the dental pattern of these rodents is strikingly reminiscent of that of their Paleogene African hystricognathous counterparts, Antoine et al. (2012) have suggested that these South American taxa could represent "the earliest stages of caviomorph evolution (i.e., their first adaptive radiation in South America)." Interestingly, the oldest known African hystricognathous rodent (Protophiomys tunisiensis; Marivaux et al. 2014), which was recently reported from Tunisia, in late middle Eocene deposits sub-coeval to those of CTA-47 and CTA-27, has incisors documenting a very similar subtype 1 of multiserial HSB (Supplementary Table S1). In North Africa, the subtype 2 of multiserial HSB is also recorded as early as the early late Eocene (Protophiomys algeriensis, Bir el Ater, Algeria; Martin 1993; Marivaux et al. 2014; Supplementary Table S1). The presence of similar incisor 
enamel conditions (multiserial subtypes 1 and 2) shared by some representatives of the most submitted), and given the close phylogenetic relationships between both groups, it might be expected that the subtype 1 of multiserial HSB (or the subtype $1+$ subtype 2 and/or the transitional 1-2) characterized the incisor enamel microstructure of the caviomorph ancestor(s) that colonized South America (seemingly shortly before their first appearance in the South American fossil record). Based on enamel incisor microstructure observations on the ?late Eocene/early Oligocene rodents from Santa Rosa, Martin (2004) advocated a similar scenario regarding the multiserial enamel pattern of the earliest caviomorphs (see also Vucetich and Vieytes 2006).

Although it was not unexpected to record an enamel with multiserial HSB exhibiting a plesiomorphic IPM arrangement [i.e., subtype 1-(2)] in late middle Eocene localities, the presence of a similar microstructure in a late Oligocene taxon (CTA-61; MUSM 2902) could appear somewhat singular. However, pre-Deseadan and post-Barrancan localities (Santa Rosa and La Cantera; Martin 2004, 2005; Vucetich et al. 2010) have also yielded rodent incisors displaying the subtype 1/subtype 1-2 of multiserial HSB (Supplementary Table S1). Besides, several Miocene taxa (e.g., the chinchilloids Perimys procerus and Cephalomys arcidens, and the cavioid Neoreomys australis) and a wide array of extant taxa (e.g., the erethizontoid Coendou mexicanus, the chinchilloids Chinchilla lanigera and Lagidium peruanum, and several cavioids such as Hydrochoeris hydrochoeris and Cavia porcellus) harbor this primitive subtype 1 condition of multiserial HSB (Martin 1992, 1994a, 1997; Supplementary Table S1), a large taxonomic and temporal distribution which then underscores the evolutionary conservative pattern of that enamel subtype. In contrast, in the Shapaja section that yields the TAR-01 locality dating from the earliest Oligocene, incisors displaying the subtype 1 [or subtype 1-(2)] of multiserial HSB are surprisingly not recorded, although this 
kind of multiserial enamel subtype is well documented in the stratigraphically close Santa

Rosa locality (Martin 2004, 2005; Supplementary Table S1). Considering that cavioids, chinchilloids, and erethizontoids include both species with incisors displaying subtype 1 of multiserial HSB and species having incisors with subtype 2 (Martin 1992, 1993, 1994a; Supplementary Table S1), the possibility exists that we would not have processed incisors with subtype 1 in our TAR-01 sample (i.e., 12 out of 650 available incisors), whereas these superfamilies are documented by cheek teeth in this locality (Boivin et al. in press; Table 1). Some extant and extinct erethizontoids (Steiromys, Chaetomys, Coendou, and Erethizon) also have incisors with transitional subtype 1-2 (Martin 1992, 1994a; Supplementary Table S1). Incisors displaying the subtype 2 of multiserial HSB are common in TAR-01 and two upper incisors (MUSM 3344 and 3353) from that locality have transitional subtype 1-2/(1)-2 (Table 4). All these incisors likely belonged to representatives of these aforementioned superfamilies (the erethizontoid Shapajamys labocensis; the cavioid or chinchilloid Eoincamys cf. E. pascuali; an unidentified chinchilloid; plus a taxon of indeterminate suprafamiliar affinities [Tarapotomys mayoensis]). The MUSM 3342 incisor, which is clearly set apart from other incisors by its large size, could be referred to Eoincamys cf. E. pascuali or Shapajamys (see Results).

The subtype 2 of multiserial HSB is also well represented by incisors from the Oligocene localities of Contamana (CTA-61 and CTA-32; Table 2), which record representatives of erethizontoids (Plesiosteiromys newelli and Paleosteiromys amazonensis), chinchilloids (Scleromys praecursor and Ucayalimys crassidens), octodontoids (Deseadomys cf. arambourgi, Adelphomyinae indet. 1 and 2, Loretomys minutus), and a taxon of indeterminate superfamily (Chambiramys; Boivin et al. 2017b; Table 1). As for the earliest stratigraphic interval considered here (late middle Eocene, Contamana; CTA-47 + CTA-27 + CTA-29; Antoine et al. 2012; Boivin et al. 2017a), except the few specimens showing the 
subtype 1 (or transitional subtypes 1-2), there are primarily incisors displaying the subtype 2 of multiserial HSB (as mentioned above; Tables 2-3). In these Eocene localities, most recorded taxa are not formally identified as representatives of extant superfamilies (Table 1), and are considered as basal caviomorphs (stem Caviomorpha: Cachiyacuy and Canaanimys). The absence of a direct association between incisors and molars precludes a formal assignation of the multiserial incisor enamel subtypes 1 and 2 [or 1-(2) or (1)-2] to either of these stem taxa. In the Eocene localities of Contamana, the alleged cavioid Eobranisamys and the octodontoid Eoespina are also recorded (Antoine et al. 2012; Boivin et al. 2017a; Table 1). They might have displayed incisors with an enamel characterized by the subtype 2 of multiserial HSB.

\section{Subtypes 2-3 and 3 of multiserial HSB}

Noteworthy is the lack of incisors displaying the subtype 3 of multiserial HSB in Eocene localities of Contamana (Tables 2-3). Among extinct and extant caviomorphs, the subtype 3 is otherwise found only in octodontoid incisors (Supplementary Table S1). This microstructural arrangement is considered to be the most derived multiserial condition on the basis of stratigraphic occurrence of taxa and biomechanical considerations (i.e., better resistance to crack propagation; Martin 1992, 1993, 1994a,b, 1997). In this context, given that other pre-Deseadan faunas in South America (Santa Rosa, La Cantera, and Shapaja TAR-01) record incisors documenting the subtype 3 of multiserial HSB (in addition to subtypes 1 and 2; Martin 2004, 2005; Vucetich et al. 2010; this paper), the absence of the subtype 3 in Eocene localities of Contamana (CTA-47, CTA-27, and CTA-29) is consistent with the primitiveness of incisor enamel microstructures recorded for rodents in these older localities. 
This is also congruent with less advanced cheek tooth pattern of recorded taxa (Antoine et al. 2012, 2016, 2017; Boivin et al. 2017a).

In the early Oligocene locality of Shapaja (TAR-01), the subtype 3 plus transitional 23 [included the transitional subtype (2)-3] are frequent (Table 4). The subtype 3 is found in three sampled incisors of TAR-01 [MUSM 3346 (upper incisor), 3349 (lower incisor), and 3352 (lower incisor); Fig. 3]. In addition to having the IPM perpendicular to prism direction, enamel of these incisors displays a strong inclination of the HSB, as well as of prisms in PE, despite the fact that some incisors with a subtype 2 or transitional subtype 2-3 have also high values for these variables (e.g., MUSM 3347, 3348, and 3351). These three microstructural features (i.e., subtype 3 of multiserial HSB, high inclination of the HSB and of the prisms in PE) are characteristic of octodontoid incisors (Martin 1992, 1993, 1994a,b, 1997, 2004). The only octodontoid described at TAR-01 is Mayomys confluens Boivin et al. in press (Table 1), the numerous cheek teeth of which have a size compatible with MUSM 3346, 3349, and 3352. The latter incisors likely could document this taxon. At TAR-01, two incisors display a transitional subtypes 2-3/(2)-3 [MUSM 3343 (lower incisor) and 3348 (upper incisor)]. This transitional subtype is also only found in octodontoids (Martin 1994a; Vieytes 2003; Vucetich and Vieytes 2006; Vucetich et al. 2010, 2015; Supplementary Table S1). At TAR-01, the presence of the transitional subtype 2-3 in addition to the subtype 3 could indicate the presence of another undocumented octodontoid. Tarapotomys mayoensis from TAR-01, of uncertain suprafamiliar assignment (Cavioidea, Chinchilloidea, or Octodontoidea; Boivin et al. in press; Table 1), could be a possible candidate for either of multiserial subtypes (2-3 and 3). Indeed, the molars of the latter are compatible in size with the MUSM 3343, 3346, 3348, 3349, and 3352 incisors (Boivin et al. in press). Interestingly, in caviomorphs, the same individual can show differences in IPM orientation between upper and lower incisors, the latter being usually characterized by the most derived subtype (Martin 1994a; Vucetich and 
Vieytes 2006). Given that MUSM 3348 is an upper incisor, similar in size to the lower document Mayomys confluens. In this context, Mayomys would have hence displayed upper and lower incisors with the transitional subtype 2-3 and the subtype 3, respectively. But this assumption of association required further morphological support (i.e., articulated craniomandibular elements) than current data allow.

Like for Eocene localities of Contamana, late Oligocene localities of this section (CTA-32 and CTA-61; Table 2) have not yielded incisors displaying the subtype 3 of multiserial HSB, although many octodontoids are identified at CTA-61 (Adelphomyinae gen. et sp. indet.1, Deseadomys cf. D. arambourgi, and octodontoid indet. 1) and CTA-32 (Loretomys minutus, aff. Eosallamys sp., Adelphomyinae gen. et sp. indet. 2, and octodontoid indet. 2) (Boivin et al. 2017b; Table 1). Only one specimen (MUSM 2903) from CTA-61 displays a transitional subtype 2-3 of multiserial HSB. Two hypotheses can be advocated for explaining the absence of incisors with the subtype 3 in these localities. Firstly, taxa with incisors exhibiting the subtype 3 of multiserial HSB were perhaps present at CTA-61 and CTA-32, but their incisors would not have been sampled for enamel microstructure analyses. Indeed, only a few incisors were analyzed from these two late Oligocene localities (seven contra 18 for the Eocene CTA localities, with notably only one incisor at CTA-32). Secondly, the numerous octodontoid taxa found at CTA-61 and CTA-32 had incisors that eventually displayed a less advanced enamel microstructure, in having multiserial HSB with the IPM characterizing the transitional subtype 2-3 rather than the subtype 3. The MUSM 2903 incisor from CTA-61 exhibits such a condition. No data are available for incisor enamel microstructure in Eosallamys and most adelphomyines (including Deseadomys). For Adelphomyinae, enamel microstructure was only studied on incisors of early Miocene 
Adelphomys and Stichomys, which display the subtype 3 of multiserial HSB (Martin 1992, 1994a; Supplementary Table S1).

\section{Conclusions}

Most of the oldest caviomorph-bearing localities (i.e., Eocene localities of Contamana, Santa Rosa, Shapaja localities, and La Cantera) have primarily yielded isolated teeth documenting plurispecific rodent assemblages. The absence of incisor-molar formal associations does not allow for any incisor accurate enamel microstructure/taxon pairings, thereby limiting drastically our comprehension of the evolution of incisor enamel microstructure in a specific group. Despite this lack, analysis of incisor enamel microstructure in a temporal context provides substantial pieces of information regarding the setting and timing of different multiserial enamel subtypes. From our current knowledge of the South American rodent fossil record, it must be underscored that the oldest localities (late middle Eocene) yield incisors displaying multiserial enamel conditions with IPM arrangements primarily typifying the subtypes 1, 1-2, and 2 of multiserial HSB. In contrast, the most crack-resistant subtype 3 of multiserial HSB is only recorded from the ?late Eocene/early Oligocene localities onward. Given the primitiveness of the Eocene caviomorph faunas, it may be expected that hystricognath pioneer(s) who colonized South America from Africa sometime during the middle Eocene, most probably had incisors that displayed a multiserial enamel with an IPM arrangement characterizing subtype 1 (or subtype $1+$ the subtype 2 and/or the transitional 12) of multiserial HSB. Based on incisor enamel microstructure observed in subsequent extinct and extant taxa, subtypes 1, 1-2, and 2 were maintained in most caviomorph superfamilies through time. In contrast, derived subtypes 2-3 and 3 condition were subsequently achieved 
but likely rapidly, as evidenced by their record as early as the ?late Eocene/early Oligocene (Santa Rosa) and early Oligocene (Shapaja and La Cantera), and they seemingly evolved iteratively, yet only in the octodontoid clade (see also Vucetich and Vieytes 2006; Vucetich et al. 2010). Continuing the analysis of incisor enamel in fossil taxa for which microstructure is undocumented and performing a cladistic assessment of morphological evidence, including a large set of morphological characters (plus those describing incisor enamel microstructure) through a comprehensive taxonomic sampling (with several phiomorphs as branching group (sensu Antoine 2003), and a wide array of caviomorphs including a maximum of Paleogene taxa, several Neogene taxa, and extant ones) would allow for a better understanding of the evolutionary pattern of different subtypes of multiserial enamel within caviomorphs. It would also be useful to point out external (ecological and paleoenvironmental) and internal (genetic and developmental) drivers for the setting of different multiserial enamel subtypes through time. Given these stimulating macroevolutionary issues, the study of enamel microstructure of incisors - and molars - should attract much more attention. When fossils are abundant and available, we then encourage scientists to systematically carry out these kinds of analyses.

\section{Acknowledgments}

We especially thank the Canaan Shipibo Native Community in the Contamana region for their help during the field seasons. Many thanks to Sylvain Adnet (ISEM, Montpellier, France), Ali J. Altamirano-Sierra (MUSM, Lima, Peru), Guillaume Billet (MNHN, Paris, France), Maëva

J. Orliac (ISEM), Francis Duranthon (Muséum de Toulouse, France), Alba Boada-Saña (Spain), François Pujos (IANIGLA, Mendoza, Argentina), Rafael M. Varas-Malca (MUSM, Lima, Peru), Julia V. Tejada-Lara (Columbia University, USA and MUSM, Lima, Peru), and 
whoever helped us in the field and in the lab. We thank Léanie Alloing-Séguier (ISEM) and

\section{References}

Antoine P-O (2003) Middle Miocene elasmotheriine Rhinocerotidae from China and Mongolia: taxonomic revision and phylogenetic relationships. Zool Scripta 32:95-118 
Antoine P-O, Abello M, Adnet S, Altamirano Sierra AJ, Baby P, Billet G, Boivin M,

Calderón Y, Candela A, Chabain J, Corfu F, Croft DA, Ganerød M, Jaramillo C, Klaus S,

Marivaux L, Navarrete RE, Orliac MJ, Parra F, Perez ME, Pujos F, Rage J-C, Ravel A, Robinet C, Roddaz M, Tejada-Lara JV, Vélez-Juarbe J, Wesselingh FP, Salas-Gismondi R (2016) A 60-million-year Cenozoic history of western Amazonian ecosystems in Contamana, eastern Peru. Gondwana Res 31:30-59

Antoine P-O, Marivaux L, Croft DA, Billet G, Ganerød M, Jaramillo C, Martin T, Orliac MJ, Tejada-Lara J, Altamirano AJ, Duranthon F, Fanjat G, Rousse S, Salas-Gismondi RS (2012) Middle Eocene rodents from Peruvian Amazonia reveal the pattern and timing of caviomorph origins and biogeography. Proc Roy Soc Lond B 279:1319-1326

Antoine P-O, Salas-Gismondi R, Pujos F, Ganerød M, Marivaux L (2017) Western Amazonia as a hotspot of mammalian biodiversity throughout the Cenozoic. J Mammal Evol 24:5-17

Arnal M, Kramarz AG, Vucetich MG, Vieytes EC (2014) A new early Miocene octodontoid rodent (Hystricognathi, Caviomorpha) from Patagonia (Argentina) and a reassessment of the early evolution of Octodontoidea. J Vertebr Paleontol 34(2):397-406

Barbière F, Marivaux L (2015) Phylogeny and evolutionary history of hystricognathous rodents from the Old World during the Tertiary: new insights into the emergence of modern "phiomorph" families. In: Cox FG, Hautier L (eds) Evolution of the Rodents: Advances in Phylogenetics, Functional Morphology and Development. Cambridge University Press, Cambridge, pp 87-138 
Blanga-Kanfi S, Miranda H, Penn O, Pupko T, DeBry RW, Huchon D (2009) Rodent phylogeny revised: analysis of six nuclear genes from all major rodent clades. BMC Evol Biol $9(1): 71$

Bertrand OC, Flynn JJ, Croft DA, Wyss AR (2012) Two new taxa (Caviomorpha, Rodentia) from the early Oligocene Tinguiririca fauna (Chile). Am Mus Novitates 3750:1-36

Boivin M, Marivaux L, Orliac MJ, Pujos F, Salas-Gismondi R, Tejada-Lara JV, Antoine P-O (2017a) Late middle Eocene caviomorph rodents from Contamana, Peruvian Amazonia. Palaeontol Elect 20.1.19A:1-50

Boivin M, Marivaux L, Candela AM, Orliac MJ, Pujos F, Salas-Gismondi R, Tejada-Lara JV, Antoine P-O (2017b) Late Oligocene caviomorph rodents from Contamana, Peruvian Amazonia. Pap Palaeontol 3(1):69-109

\author{
Boivin M, Marivaux L, Pujos F, Salas-Gismondi R, Tejada-Lara JV, Varas-Malca RM, \\ Antoine P-O Early Oligocene caviomorph rodents from Shapaja, Peruvian Amazonia. \\ Palaeontogr Abt A in press.
}

Boyde A (1997) Microstructure of enamel. In: Chadwick DJ, Cardew G (eds) Dental Enamel. Wiley, Chichester (Ciba Foundation Symposium 205), pp 18-31

Bugge J (1985) Systematic value of the carotid arterial pattern in rodents. In: Luckett WP, Hartenberger J-L (eds), Evolutionary Relationships Among Rodents: A Multidisciplinary Analysis. Plenum Press, New York, pp 355-379 
Churakov G, Sadasivuni MK, Rosenbloom KR, Huchon D, Brosius J, Schmitz J (2010)

Rodent evolution: back to the root. Mol Biol Evol 27(6):1315-1326

Coster P, Benammi M, Lazzari V, Billet G, Martin T, Salem M, Bilal AA, Chaimanee Y, Schuster M, Valentin X, Brunet M, Jaeger J-J (2010) Gaudeamus lavocati sp. nov. (Rodentia, Hystricognathi) from the early Oligocene of Zallah, Libya: first African caviomorph?

Naturwissenschaften 97:697-706

Dawson MR (1977) Late Eocene rodent radiation: North America, Europe and Asia. Geobios Mém Spéc 1:195-209

Durette-Desset M-C (1971) Essai de classification des Nématodes Héligmosomes. Corrélation avec la paléobiogéographie des hôtes. Mém Mus Natl Hist Nat, Série A, Zoologie 49:1-126

Fabre P-H, Hautier L, Dimitrov D, Douzery EJ (2012) A glimpse on the pattern of rodent diversification: a phylogenetic approach. BMC Evol Biol 12(1):88

Frailey CD, Campbell KE (2004) Palaeogene rodents from Amazonian Peru: the Santa Rosa local fauna. In: Campbell KE (ed) The Palaeogene Mammalian Fauna of Santa Rosa, Amazonian Peru. Nat Hist Mus Los Angeles County, Science Series 40:71-130

George W (1985) Reproductive and chromosomal characters of ctenodactylids as a key to their evolutionary relationships. In: Luckett WP, Hartenberger J-L (eds) Evolutionary 
Relationships Among Rodents: A Multidisciplinary Analysis. Plenum Press, New York, pp $453-474$

Hartenberger J-L (1975) Nouvelles découvertes de rongeurs dans le Déseadien (Oligocène inférieur) de Salla Luribay (Bolivie). C R Acad Sc Paris 280:427-430

Hartenberger J-L, Mégard F, Sigé B (1984) Faunules à rongeurs de l'Oligocène inférieur à Lircay (Andes du Pérou Central) : datation d'un épisode karstique; intérêt paléobiogéographique des remplissages tertiaires en Amérique du Sud. C R Acad Sc Paris 299(9):565-568

Hoffstetter R (1971) Le peuplement mammalien de l'Amérique du Sud. Rôle des continents austraux comme centres d'origine, de diversification et de dispersion pour certain groupes mammaliens. An Acad Brasil Cienc 43 (Sup):125-143

Hoffstetter R (1972) Origine et dispersion des Rongeurs Hystricognathes. C R Acad Sc Paris $274: 2867-2870$

Hoffstetter R (1975) El origen de los Caviomorphoa y el problema de los Hystricognathi (Rodentia). Actas del Primer Congreso Argentino de Paleontologia y Bioestratigraphia, Tucumán, Agosto 1974, 2:505-528

Hoffstetter R, Lavocat R (1970) Découverte dans le Déséadien de Bolivie des genres pentalophodontes appuyant les affinités africaines des rongeurs caviomorphes. C R Acad Sc Paris 271:172-175 
Huchon D, Douzery EJ (2001) From the Old World to the New World: a molecular chronicle of the phylogeny and biogeography of hystricognath rodents. Mol Phyl Evol 20(2):238-251

Huchon D, Catzeflis FM, Douzery EJP (2000) Variance of molecular datings, evolution of rodents, and the phylogenetic affinities between Ctenodactylidae and Hystricognathi. Proc Roy Soc Lond B 267:393-402

Huchon D, Chevret P, Jordan U, Kilpatrick CW, Ranwez V, Jenkins PD, Brosius J, Schmitz, J (2007) Multiple molecular evidences for a living mammalian fossil. Proc Natl Acad Sci USA 104(18):7495-7499

Huchon D, Madsen O, Sibbald MJ, Ament K, Stanhope MJ, Catzeflis F, Jong WW de, Douzery EJ (2002) Rodent phylogeny and a timescale for the evolution of Glires: evidence from an extensive taxon sampling using three nuclear genes. Mol Biol Evol 19(7):1053-1065

Hugot JP (1982) Sur le genre Wellcomia (Oxyuridae, Nematoda), parasite de Rongeurs archaïques. Bull Mus Natl Hist Nat Paris 4:25-48

Hunter J (1771) The Natural History of the Human Teeth. Explaining their Structure, Use, Formation, Growth, and Diseases. Robert Hardwicke, London

Kalthoff D (2000) Die Schmelzmikrostruktur in den Incisiven der hamsterartigen Nagetiere und anderer Myomorpha (Rodentia, Mammalia). Palaeontographica Abt A 259:1-193 
Kalthoff D (2006) Incisor enamel microstructure and its implications to the systematics of Eurasian Oligocene and lower Miocene hamsters. Palaeontographica Abt A 277:67-80

Klaus S, Magalhaes C, Salas-Gismondi R, Gross M, Antoine P-O (2017) Paleogene and Neogene brachyurans of the Amazon basin: a revised first appearance date for primary freshwater crabs (Crustacea, Brachyura, Trichodactylidae). Crustaceana 90:953-967

Koenigswald W von (1980) Schmelzstruktur und Morphologie in den Molaren der Arvicolidae (Rodentia). Abh Senckenberg Nat Ges 539:1-129

Koenigswald W von (1985) Evolutionary trends in the enamel of rodent incisors. In: Luckett WP, Hartenberger J-L (eds) Evolutionary Relationships Among Rodents: A Multidisciplinary Analysis. Plenum Press, New York, pp 403-422

Koenigswald W von, Sander PM (1997) Glossary of terms used for enamel microstructures. In: Koenigswald W von, Sander PM (eds) Tooth Enamel Microstructure. Balkema, Rotterdam, pp 267-280

Koenigswald W von, Martin T, Pfretzschner HU (1993) Phylogenetic interpretation of enamel structures in mammalian teeth: possibilities and problems. In: Szalay FS, Novacek MJ, McKenna MC (eds) Mammal Phylogeny, Placentals. Springer-Verlag, New York, pp 303314

Korth WW (1984) Earliest Tertiary evolution and radiation of rodents in North America. Bull Carnegie Mus Nat Hist 24:1-71 
Korvenkontio VA (1934) Mikroskopische Untersuchungen an Nagerincisiven, unter Hinweis auf die Schmelzstruktur der Backenzähne. Ann Zool Soc Zool-Bot Fenn Vanamo 2:1-274

Lavocat R (1969) La systématique des rongeurs hystricomorphes et la dérive des continents. C R Acad Sc Paris 269:1496-1497

Lavocat R (1971) Affinités systématiques des caviomorphes et des phiomorphes et origine africaine des caviomorphes. An Acad brasil Cienc 41(Sup):515-622

Lavocat R (1973) Les rongeurs du Miocène d'Afrique orientale. 1. Miocène inférieur. Mem. Trav EPHE, Montpellier 1:1-284

Lavocat R (1974a) The interrelationships between the African and South American rodents and their bearing on the problem of the origin of South American monkeys. J Hum Evol $3(4): 323-326$

Lavocat R (1974b) What is an hystricomorph? In: Rowlands IW, Weir BJ (eds) The Biology of Hystricomorph Rodents. Symp Zool Soc Lond 34:7-20, 55-60

Lavocat R (1976) Rongeurs caviomorphes de l'Oligocène de Bolivie. Rongeurs du bassin déséadien de Salla. Palaeovertebrata 7:15-90

Lavocat R (1977a) Sur l'origine des faunes sud-américaines de mammifères du Mésozoïque terminal et du Cénozoïque ancien C R Acad Sc Paris 285:1423-1426 
Lavocat R (1977b) Les relations faunistiques Afrique-Amérique. Colloque de Montpellier (12-16 Sept.). Mem Trav EPHE, Montpellier 1(4):169-179

Lavocat R (1980) The implications of rodent paleontology and biogeography to the geographical sources and origin of the platyrrhine primates. In: Ciochon RL, Chiarelli AB (eds) Evolutionary Biology of the New World Monkeys and Continental Drift. Plenum Press, New York, pp. 93-102

Loomis FB (1914) The Deseado Formation of Patagonia. Rumford Press, Concord, New Hampshire

Luckett WP, Hartenberger J-L (1993) Monophyly or polyphyly of the order Rodentia: possible conflict between morphological and molecular interpretations. J Mammal Evol $1(2): 127-147$

Marivaux L, Adaci M, Bensalah M, Gomes Rodrigues H, Hautier L, Mahboubi M, Mebrouk F, Tabuce R, Vianey-Liaud M (2011) Zegdoumyidae (Rodentia, Mammalia), stem anomaluroid rodents from the early to middle Eocene of Algeria (Gour Lazib, western Sahara): new dental evidence. J Syst Palaeontol 9:563-588

Marivaux L, Boivin M, Mahboubi M Incisor enamel microstructure of hystricognathous and anomaluroid rodents from the earliest Oligocene of Dakhla, Atlantic Sahara (Morocco). J Mammal Evol submitted 
Marivaux L, Essid EM, Marzougui W, Khayati Ammar H, Adnet S, Marandat B, Merzeraud

G, Tabuce R, Vianey-Liaud M (2014) A new and primitive species of Protophiomys

(Rodentia, Hystricognathi) from the late middle Eocene of Djebel el Kébar, Central Tunisia.

Palaeovertebrata 38(1-e2):1-17

Marivaux L, Lihoreau F, Manthi KF, Ducrocq R (2012) A new basal phiomorph (Rodentia, Hystricognathi) from the late Oligocene of Lokone (Turkana Basin, Kenya). J Vertebr

Paleontol 32(3):646-657

Marivaux L, Vianey-Liaud M, Jaeger J-J (2004) High-level phylogeny of early Tertiary rodents: dental evidence. Zool J Linn Soc 142(1):105-134

Marivaux L, Welcomme JL, Vianey-Liaud M, Jaeger J-J (2002) The role of Asia in the origin and diversification of hystricognathous rodents. Zool Scripta 31:225-239

Martin T (1992) Schmelzstruktur in den Inzisiven alt- und neuweltlicher hystricognather Nagetiere. Palaeovertebrata Mém extra:1-168

Martin T (1993) Early rodent incisor enamel evolution: phylogenetic implications. J Mammal Evol 1(4):227-254

Martin T (1994a) On the systematic position of Chaetomys subspinosus (Rodentia:

Caviomorpha) based on evidence from the incisor enamel microstructure. J Mammal Evol 2(2):117-131 
Martin T (1994b) African origin of caviomorph rodents is indicated by incisor enamel microstructure. Paleobiology 20:5-13

Martin T (1995) Incisor enamel microstructure and phylogenetic interrelationships of Pedetidae and Ctenodactyloidea (Rodentia). Berliner Geowiss Abh 16:693-707

Martin T (1997) Incisor enamel microstructure and systematics in rodents. In: Koenigswald W von, Sander PM (eds) Tooth Enamel Microstructure. Balkema, Rotterdam, pp 163-175

Martin T (2004) Incisor enamel microstructure of South America's earliest rodents: implications for caviomorph origin and diversification. In: Campbell KE Jr (ed) The Palaeogene Mammalian Fauna of Santa Rosa, Amazonian Peru. Nat Hist Mus Los Angeles County, Los Angeles, pp 131-140

Martin T (2005) Incisor Schmelzmuster diversity in South America's oldest rodent fauna and early caviomorph history. J Mammal Evol 12(3/4):405-417

Martin T (2007) Incisor enamel microstructure and the concept of Sciuravida. Bull Carnegie Mus Nat Hist 39:127-140

Meng J (1990) The auditory region of Reithroparamys delicatissimus (Mammalia, Rodentia) and its systematic implications. Am Mus Novitates 2972:1-35

Mones A, Castiglioni LR (1979) Additions to the knowledge on fossil rodents of Uruguay (Mammalia: Rodentia). Paläontol Z 53:77-87 
Montgelard C, Forty E, Arnal V, Matthee CA (2008) Suprafamilial relationships among

Rodentia and the phylogenetic effect of removing fast-evolving nucleotides in mitochondrial, exon and intron fragments. BMC Evol Biol 8(321):1-16

Mossman HW, Luckett WP (1968) Phylogenetic relationship of the African mole rat (Bathyergus janetta) as indicated by the fetal membranes. Am Zool 8:806

Nedbal MA, Honeycutt RL, Schilitter DA (1996) Higher-level systematics of rodents (Mammalia, Rodentia): evidence from the mitochondrial 12S rRNA gene. J Mammal Evol 3(3):201-237

Pascual R, Vucetich MG, Scillato-Yané GJ (1990) Extinct and Recent South American and Caribbean edentates and rodents: outstanding examples of isolation. In: Azzarolin A (ed) Biogeographical Aspects of Insularity. Atti Convegni Lincei 87:627-640

Patterson B, Pascual R (1968) New echimyid rodents from the Oligocene of Patagonia, and a synopsis of the family. Breviora Mus Comp Zool 301:1-14

Patterson B, Wood AE (1982) Rodents from the Deseadan Oligocene of Bolivia and the relationships of the Caviomorpha. Bull Mus Comp Zool 149:371-543

Poux C, Chevret P, Huchon D, De Jong WW, Douzery EJ (2006) Arrival and diversification of caviomorph rodents and platyrrhine primates in South America. Syst Biol 55(2):228-244 
Quentin JC (1973) Affinités entre les Oxyures parasites de rongeurs Hystricidés,

Erethizontidés et Dinomyidés. Intérêt paléobiogéographique. C R Acad Sc Paris 276:20152017

Rensberger JM, Koenigswald W von (1980) Functional and phylogenetic interpretation of enamel microstructure in rhinoceroses. Paleobiology 6(4):477-495

Schreger BNG (1800) Beitrag zur Geschichte der Zähne. Beitr Zerglied 1:1-7

Tabuce R, Delmer C, Gheerbrant E (2007) Evolution of the tooth enamel microstructure in the earliest proboscideans (Mammalia). Zool J Linn Soc 149(4):611-628

Vélez-Juarbe J, Martin T, MacPhee RDE, Ortega-Ariza D (2014) The earliest Caribbean rodents: Oligocene caviomorphs from Puerto Rico. J Vertebr Paleontol 34:157-163

Vieytes EC (2003) Microestructura del esmalte de roedores Hystricognathi sudamericanos fósiles y vivientes: significado morfofuncional y filogenético. PhD Dissertation, Universidad Nacional de La Plata, Argentina

Vucetich, MG (1989) Rodents (Mammalia) of the Lacayani fauna revisited (Deseadan, Bolivia). Comparison with new Chinchillidae and Cephalomyidae from Argentina. Bull Mus Natl Hist Nat 11(4):233-247 
Vucetich MG, Vieytes EC (2006) A middle Miocene primitive octodontoid rodent and its bearing on the early evolutionary history of the Octodontoidea. Palaeontographica Abt A 8191

Vucetich MG, Arnal M, Deschamps CM, Pérez ME, Vieytes EC (2015) A brief history of caviomorph rodents as told by the fossil record. In: Vassallo AI, Antenucci D (eds) Biology of Caviomorph Rodents: Diversity and Evolution. Soc Argentina Est Mam (SAREM), Buenos Aires, Argentina, pp 11-62

Vucetich MG, Vieytes EC, Pérez ME, Carlini AA (2010) The rodents from La Cantera and the early evolution of caviomorphs in South America In: Madden RH, Carlini AA, Vucetich MG, Kay RF (eds) The Paleontology of Gran Barranca, Evolution and Environmental Change through the Middle Cenozoic of Patagonia. Cambridge University Press, Cambridge, pp 189201

Wood AE (1949) A new Oligocene rodent genus from Patagonia. Am Mus Novitates 1435:154

Wood AE (1950) Porcupines, paleogeography, and parallelism. Evolution 4(1):87-98

Wood AE (1959) Eocene radiation and phylogeny of the rodents. Evolution 13(3):354-361

Wood AE (1962) The early Tertiary rodents of the family Paramyidae. Trans Am Phil Soc $52: 1-261$ 
Wood AE (1965) Grades and clades among rodents. Evolution 19(1):115-130

Wood AE (1972) An Eocene hystricognathous rodent from Texas: its significance in interpretations of continental drift. Science 175(4027):1250-1251

Wood AE (1973) Eocene rodents, Pruett Formation, southwest Texas: their pertinence to the origin of the South American Caviomorpha. Pearce-Sellards Series Texas Mem Mus 20:1-41

Wood AE (1974) The evolution of the Old World and New World hystricomorphs. Symp Zool Soc Lond 34:21-60

Wood AE (1975) The problem of the hystricognathous rodents. Univ Mich Pap Paleontol $12: 75-80$

Wood AE (1980) The origin of the caviomorph rodents from a source in Middle America. In: Ciochon RL, Chiarelli AB (eds) Evolutionary Biology of the New World Monkeys and Continental Drift. Plenum Press, New York, pp 79-91

Wood AE (1983) The radiation of the Order Rodentia in the southern continents: the dates, numbers and sources of the invasions. Schriftenr, Geol Wiss Berlin 19(20):381-394

Wood AE (1984) Hystricognathy in the North American Oligocene rodent Cylindrodon and the origin of the Caviomorpha. In: Mengel RM (ed) Papers in Vertebrate Paleontology Honoring Robert Warren Wilson. Carnegie Mus Nat Hist Spec Pub 9:151-160 
Wood AE (1985a) The relationships, origin and dispersal of the hystricognathous rodents. In:

Luckett WP, Hartenberger J-L (eds) Evolutionary Relationships Among Rodents: A

Multidisciplinary Analysis. Plenum Press, New York, pp 475-513

Wood AE (1985b) Northern waif primates and rodents. In: Stehli FS, Webb SD (eds) The Great American Biotic Interchange. Plenum Press, New York, pp 267-282

Wood AE, Patterson B (1959) The rodents of the Deseadan Oligocene of Patagonia and the beginnings of South American rodent evolution. Bull Mus Comp Zool 120:281-428

Wood AE, Patterson B (1970) Relationships among hystricognathous and hystricomorphous rodents. Mammalia 34(4):628-639

Wyss AR, Flynn JJ, Norell MA, Swisher CC III, Charrier R, Novacek MJ, McKenna MC (1993) South America's earliest rodent and recognition of a new interval of mammalian evolution. Nature 365:434-437

\section{Figure captions:}

Fig. 1 Scanning electron micrographs of caviomorph incisors from Paleogene localities of Peruvian Amazonia. a-b. lower incisor enamel (MUSM 2803) from CTA-27 with a subtype 1 multiserial HSB; c-d. upper incisor enamel (MUSM 3353) from TAR-01 with an intermediate subtype 1-2 multiserial HSB. a, c. overview of longitudinal section; b, d. detail of PI in longitudinal section. PI, Portio interna; PE, Portio externa; HSB, Hunter Schreger Bands; P, prism; IPM, interprismatic matrix; D, dentine. Scale bar equals $10 \mu \mathrm{m}$. 
Fig. 2 Scanning electron micrographs of caviomorph incisors from Paleogene localities of Peruvian Amazonia. a-b. upper incisor enamel (MUSM 2840) from CTA-29 with a subtype 2 multiserial HSB; c-d. lower incisor enamel (MUSM 2903) from CTA-61 with an intermediate subtype 2-3 multiserial HSB. a, c. overview of longitudinal section; b, d. detail of PI in longitudinal section. For abbreviations, see caption of the Figure 1. Scale bar equals $10 \mu \mathrm{m}$.

Fig. 3 Scanning electron micrographs of caviomorph incisors from Paleogene localities of Peruvian Amazonia. a-b. upper incisor enamel (MUSM 3346) from TAR-01; c-d. lower incisor enamel (MUSM 3352) from TAR-01 with a subtype 3 multiserial HSB. a, c. overview of longitudinal section; b, d. detail of PI in longitudinal section. For abbreviations, see caption of the Figure 1. Scale bar equals $10 \mu \mathrm{m}$.

\section{Table captions:}

Table 1 List of taxa found at Contamana (CTA-47, CTA-27, CTA-29, CTA-61, and CTA-32) and Shapaja (TAR-01) localities.

Table 2 Incisor enamel microstructure characters of the studied specimens from CTA-47, CTA-29, CTA-32 and CTA-61.

Table 3 Incisor enamel microstructure characters of the studied specimens from CTA-27.

Table 4 Incisor enamel microstructure characters of the studied specimens from TAR-01. 


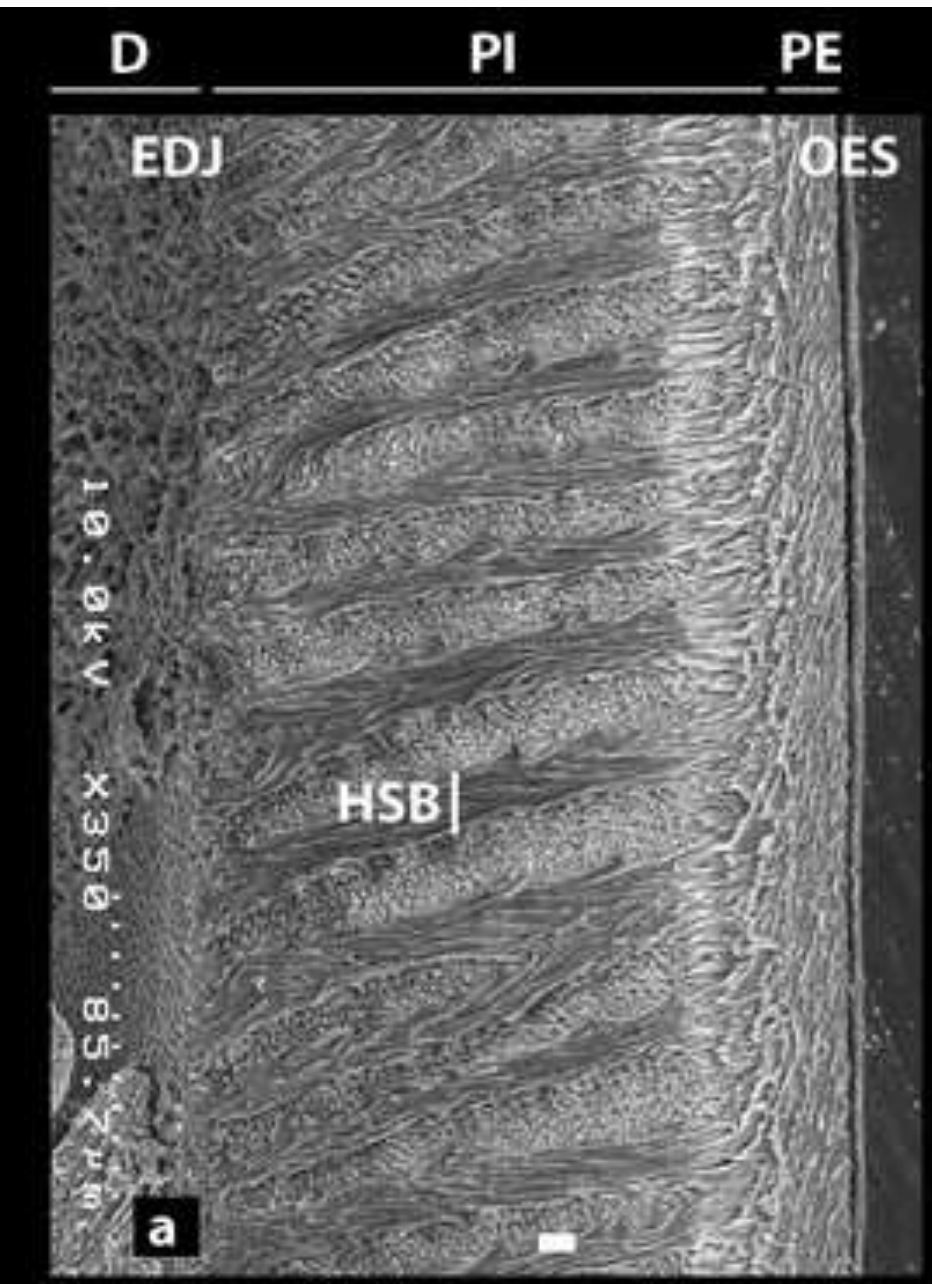

D $\quad$ PI $\quad$ PE
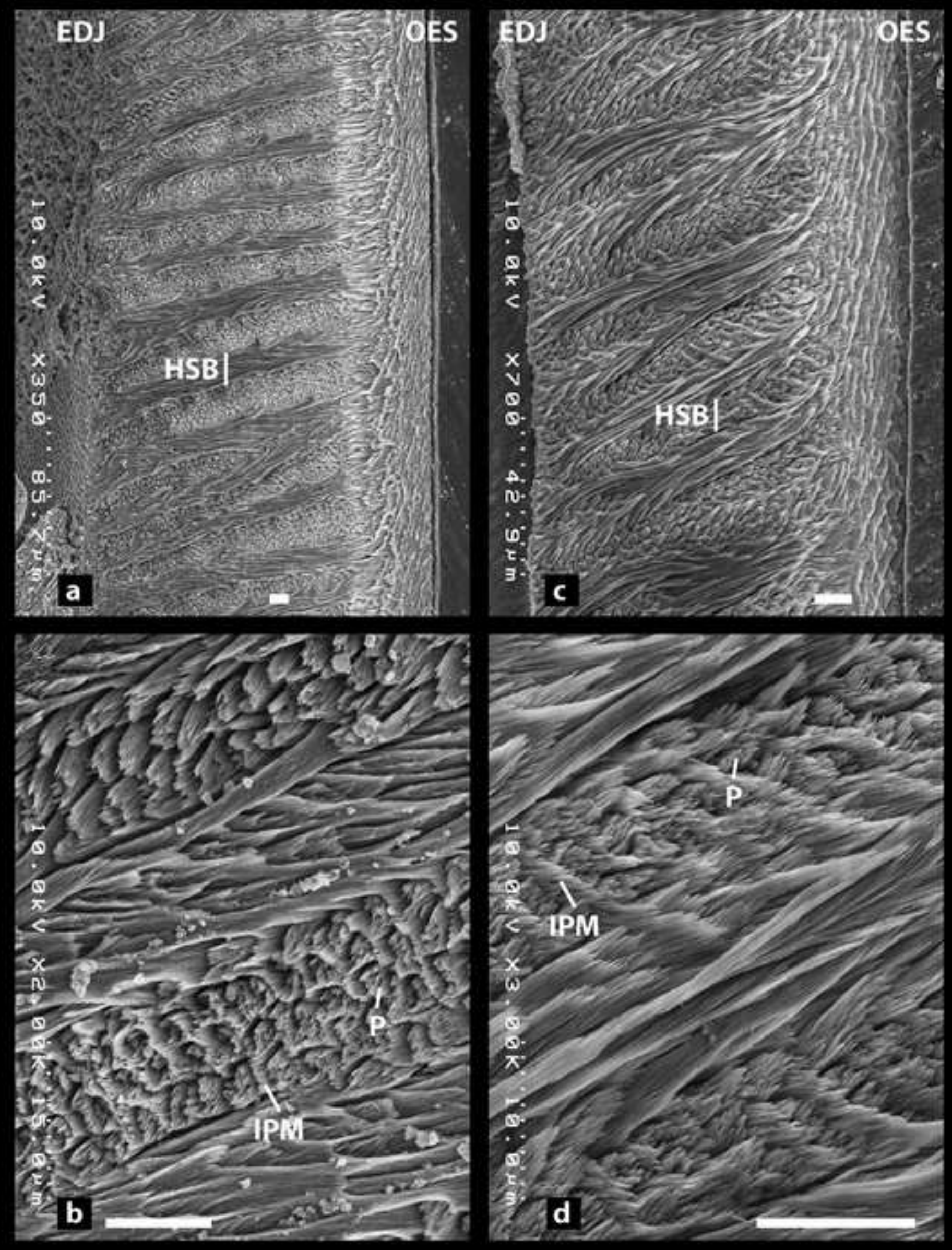

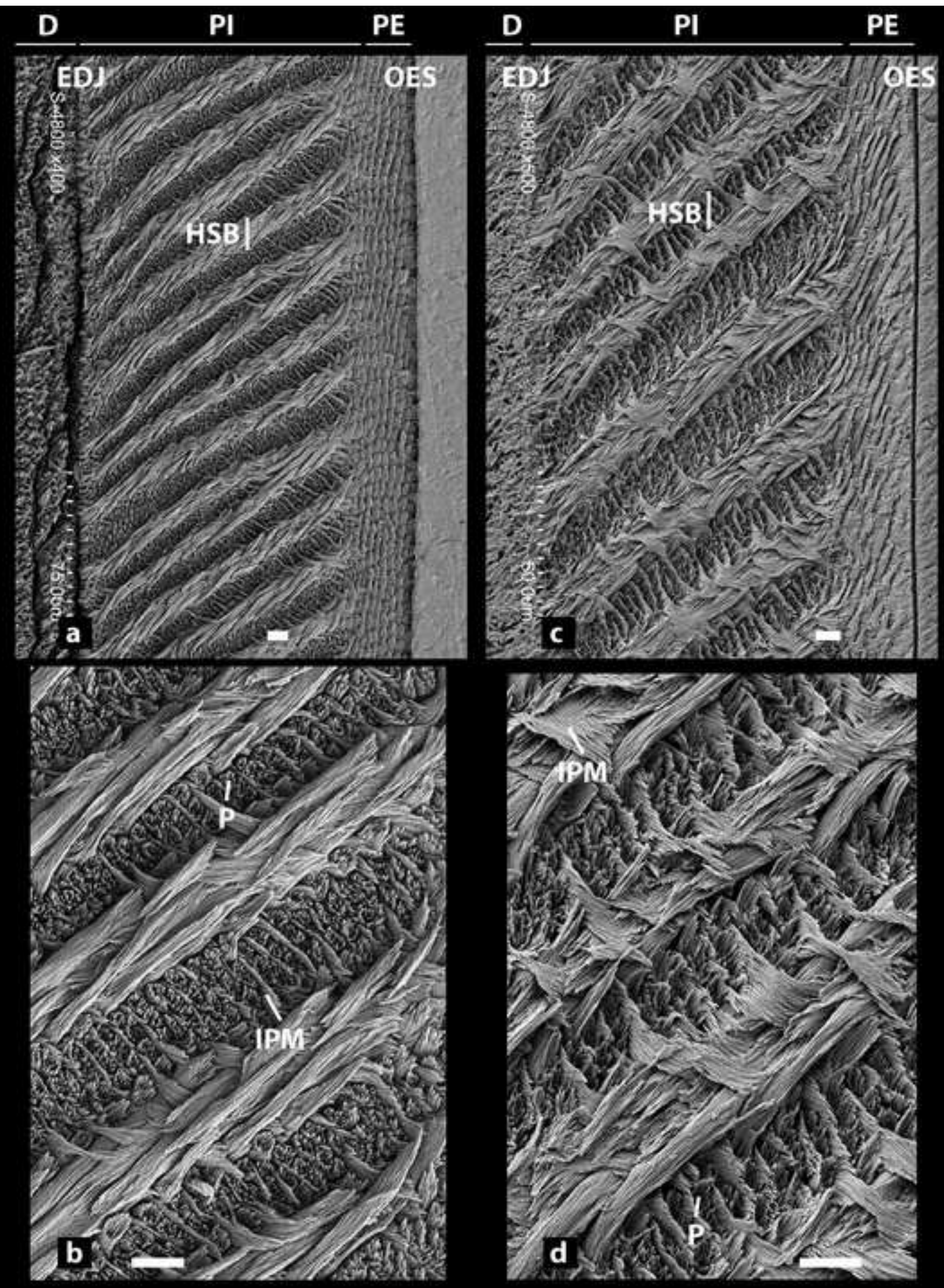


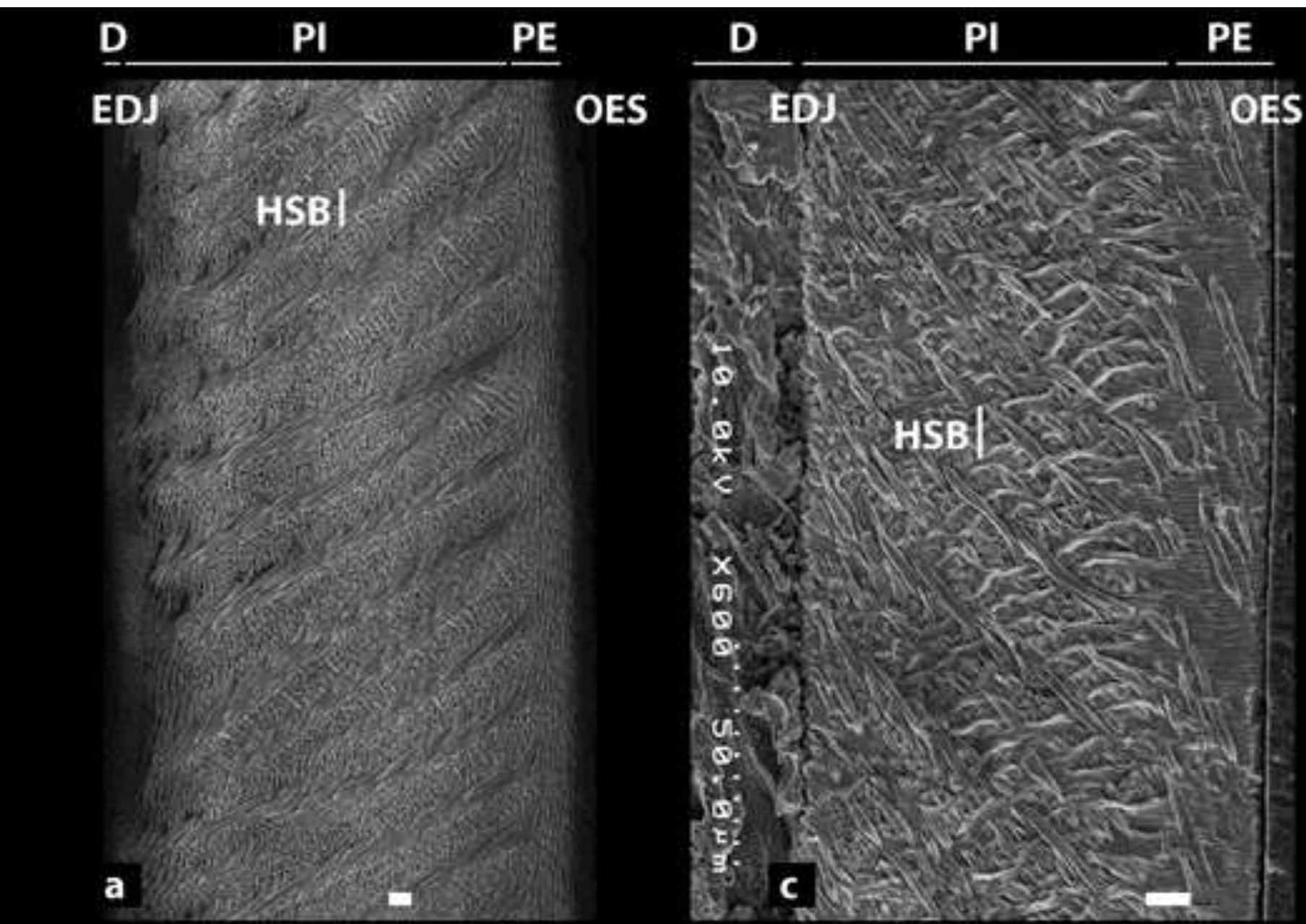
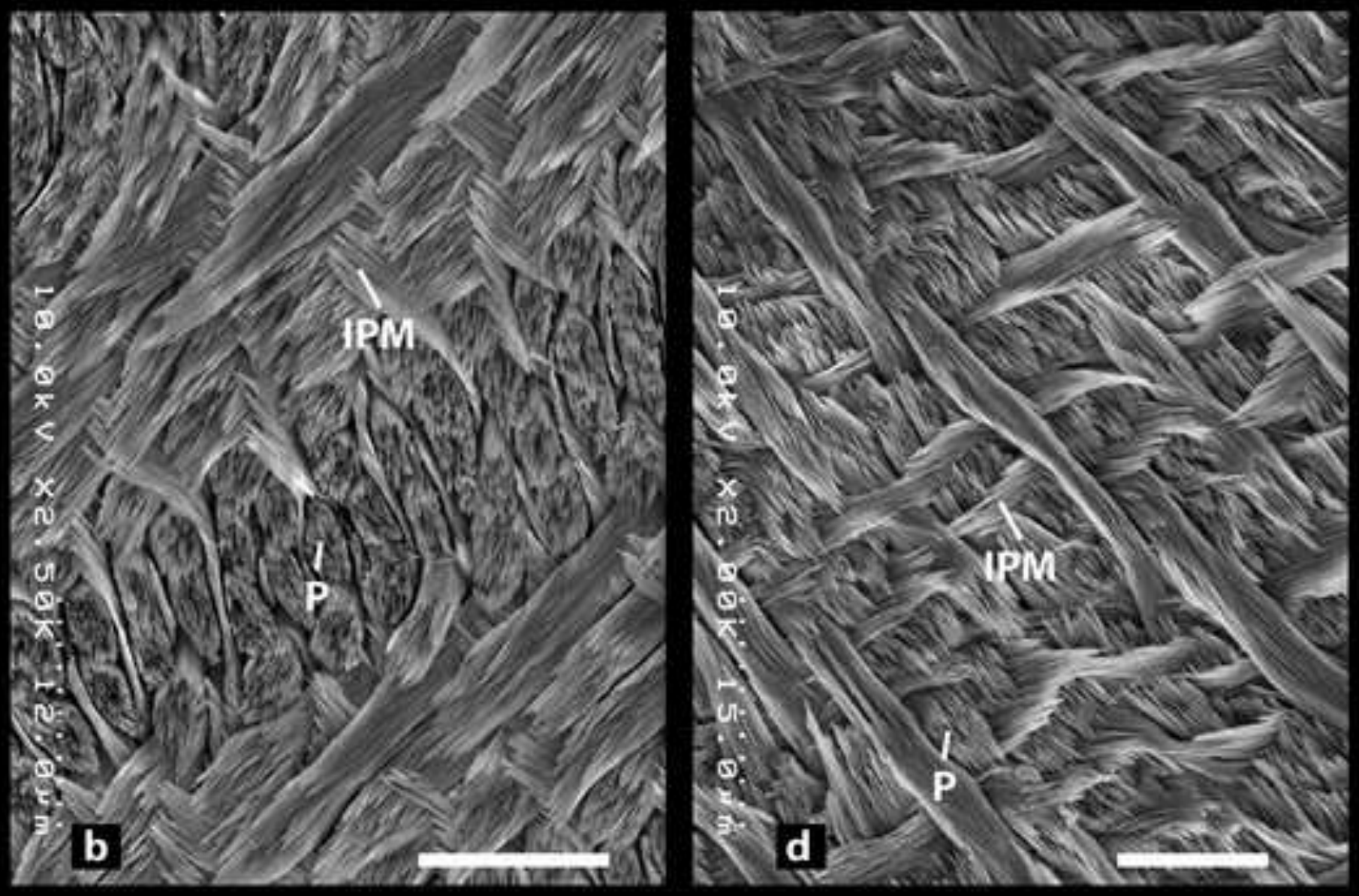


\begin{tabular}{|c|c|c|c|}
\hline Taxa & Locality & Age & References \\
\hline \multicolumn{4}{|l|}{ ERETHIZONTOIDEA } \\
\hline Shapajamys labocensis & TAR-01 & Early Oligocene & Boivin et al., in press \\
\hline Paleosteiromys amazonensis & CTA-32 & Late Oligocene & Boivin et al., 2017b \\
\hline \multicolumn{4}{|l|}{ ?ERETHIZONTOIDEA } \\
\hline Plesiosteiromys newelli & CTA-61 & Late Oligocene & Boivin et al., 2017b \\
\hline ?Erethizontoidea indet. & CTA-61 & Late Oligocene & Boivin et al., 2017b \\
\hline \multicolumn{4}{|l|}{ OCTODONTOIDEA } \\
\hline cf. Eoespina sp. & CTA-27 & late Middle Eocene & Antoine et al., 2012; Boivin et al., 2017a \\
\hline Mayomys confluens & TAR-01 & Early Oligocene & Boivin et al., in press \\
\hline Loretomys minutus & CTA-32 & Late Oligocene & Boivin et al., 2017b \\
\hline aff. Eosallamys sp. & CTA-32 & Late Oligocene & Boivin et al., 2017b \\
\hline $\begin{array}{l}\text { aff. Mayomys sp. (Octodontoidea } \\
\text { indet. 1) }\end{array}$ & CTA-61 & Late Oligocene & Boivin et al., 2017b; Boivin et al., in press \\
\hline Octodontoidea indet. 2 & CTA-32 & Late Oligocene & Boivin et al., 2017b \\
\hline \multicolumn{4}{|l|}{ ECHIMYIDAE } \\
\hline Adelphomyinae indet. 1 & CTA-61 & Late Oligocene & Boivin et al., 2017b \\
\hline Adelphomyinae indet. 2 & CTA-32 & Late Oligocene & Boivin et al., 2017b \\
\hline Deseadomys cf. arambourgi & CTA-61 & Late Oligocene & Boivin et al., 2017b \\
\hline
\end{tabular}

CAVIOIDEA

Eobranisamys javierpradoi

CTA-27 late Middle Eocene

Antoine et al., 2012; Boivin et al., 2017a

CHINCHILLOIDEA DINOMYIDAE

Chinchilloidea indet.

TAR-01 Early Oligocene

Boivin et al., in press

Scleromys praecursor

CTA-61 Late Oligocene

Boivin et al., 2017b

?CHINCHILLOIDEA

Eoincamys cf. pascuali

TAR-01 Early Oligocene

Boivin et al., in press

Ucayalimys crassidens

CTA-32 Late Oligocene

Boivin et al., 2017b

CAVIOIDEA or CHINCHILLOIDEA

Cavioidea or Chinchilloidea indet. CTA-29 late Middle Eocene

Boivin et al., 2017a

\section{SUPERFAMILY INDETERMINATE}

Cachiyacuy contamanensis

Cachiyacuy cf. contamanensis 2

Cachiyacuy kummeli

?Cachiyacuy kummeli

Canaanimys maquiensis

?Canaanimys sp.

Pozomys ucayaliensis

Tarapotomys mayoensis

Chambiramys sylvaticus

Chambiramys shipiborum

Caviomorpha indet. 1

Caviomorpha indet. 5

Caviomorpha indet. 6

Caviomorpha indet. 1

Caviomorpha indet. 2

Caviomorpha indet. 3

Caviomorpha indet. 4

Caviomorpha indet. 5
CTA-27 late Middle Eocene

CTA-29 late Middle Eocene

CTA-27 late Middle Eocene

CTA-47 late Middle Eocene

CTA-27 late Middle Eocene

CTA-47 late Middle Eocene

CTA-29 late Middle Eocene

TAR-01 Early Oligocene

CTA-61 Late Oligocene

CTA-32 Late Oligocene

CTA-47 late Middle Eocene

CTA-29 late Middle Eocene

CTA-29 late Middle Eocene

CTA-61 Late Oligocene

CTA-61 Late Oligocene

CTA-61 Late Oligocene

CTA-61 Late Oligocene

CTA-32 Late Oligocene
Antoine et al., 2012; Boivin et al., 2017a

Boivin et al., 2017a

Antoine et al., 2012; Boivin et al., 2017a

Boivin et al., 2017a

Antoine et al., 2012; Boivin et al., 2017a

Boivin et al., 2017a

Boivin et al., 2017a

Boivin et al., in press

Boivin et al., 2017b

Boivin et al., 2017b

Boivin et al., 2017a

Boivin et al., 2017a

Boivin et al., 2017a

Boivin et al., 2017b

Boivin et al., 2017b

Boivin et al., 2017b

Boivin et al., 2017b

Boivin et al., 2017b 


\begin{tabular}{|c|c|c|c|c|c|c|c|c|c|c|c|c|c|c|c|c|c|c|}
\hline & Locality & $\begin{array}{l}\text { Specimen } \\
\text { number }\end{array}$ & Incisor & $\begin{array}{l}\text { Incisor width } \\
(\mathrm{mm})\end{array}$ & $\begin{array}{c}\text { Enamel } \\
\text { thickness }(\mu \mathrm{m})\end{array}$ & $\begin{array}{c}\text { Percentage of } \\
\mathrm{PE}\end{array}$ & $\begin{array}{l}\text { Percentage of } \\
\text { PI }\end{array}$ & $\begin{array}{l}\text { Inclination of } \\
\text { prisms in } \mathrm{PE}\left({ }^{\circ}\right)\end{array}$ & $\begin{array}{l}\text { Inclination of } \\
\text { HSB }\left(\left(^{\circ}\right)\right.\end{array}$ & $\begin{array}{c}\text { Prisms } \\
\text { per HSB }\end{array}$ & $\begin{array}{c}\text { Prisms of } \\
\text { transitional zone }\end{array}$ & $\begin{array}{c}\text { Division } \\
\text { HSB }\end{array}$ & Prism cross section & Anastomose IPM & $\begin{array}{l}\text { Angle crystallites of } \\
\text { IPM and prism in PI }\end{array}$ & $\begin{array}{l}\text { IPM configuration } \\
\text { in PI }\end{array}$ & $\begin{array}{l}\text { Multiserial subtype } \\
\text { (sbt) }\end{array}$ & Figure \\
\hline $\begin{array}{l}\text { Mean } \\
\text { Min } \\
\text { Max }\end{array}$ & CTA-47 & MUSM 2649 & $\begin{array}{c}\text { upper } \\
\text { left }\end{array}$ & 1.0 & $\begin{array}{l}74 \\
62 \\
79 \\
\end{array}$ & & & & $\begin{array}{l}36 \\
28 \\
48 \\
\end{array}$ & $2-3$ & well marked & no & flattened & frequent & Acute $\left(c .30^{\circ}\right)$ & sheet-like & Multiserial sbt 2 & \\
\hline $\begin{array}{l}\text { Mean } \\
\text { Min } \\
\text { Max }\end{array}$ & CTA-47 & MUSM 2650 & ? & 1.2 & $\begin{array}{l}155 \\
79 \\
167\end{array}$ & $\begin{array}{l}16 \\
14 \\
18\end{array}$ & $\begin{array}{l}83 \\
79 \\
84\end{array}$ & $\begin{array}{l}69 \\
48 \\
81\end{array}$ & $\begin{array}{l}23 \\
14 \\
30\end{array}$ & $2-4$ & well marked & $\begin{array}{c}\text { very } \\
\text { frequent }\end{array}$ & flattened & very frequent & Acute (c. $\left.30^{\circ}\right)$ & $\begin{array}{l}\text { sheath-like / sheet- } \\
\text { like }\end{array}$ & Multiserial sbt (1)-2 & \\
\hline $\begin{array}{l}\text { Mean } \\
\text { Min } \\
\text { Max }\end{array}$ & СТA-29 & MUSM 2840 & $\begin{array}{l}\text { lower } \\
\text { right }\end{array}$ & 1.1 & $\begin{array}{l}174 \\
171 \\
175 \\
\end{array}$ & $\begin{array}{l}20 \\
18 \\
21 \\
\end{array}$ & $\begin{array}{l}76 \\
75 \\
78 \\
\end{array}$ & $\begin{array}{l}84 \\
77 \\
90 \\
\end{array}$ & $\begin{array}{l}33 \\
27 \\
39 \\
\end{array}$ & $2-4$ & well marked & $\begin{array}{c}\text { very } \\
\text { frequent }\end{array}$ & round / flattened & rare & Acute $\left(32-58^{\circ}\right)$ & sheet-like & Multiserial sbt 2 & Fig. 2a-b \\
\hline $\begin{array}{c}\text { Mean } \\
\text { Min } \\
\text { Max }\end{array}$ & СTA-32 & MUSM 2873 & lower & 1.0 & $\begin{array}{l}88 \\
88 \\
89 \\
\end{array}$ & $\begin{array}{l}27 \\
25 \\
29 \\
\end{array}$ & $\begin{array}{l}70 \\
66 \\
72 \\
\end{array}$ & $\begin{array}{l}74 \\
56 \\
88 \\
\end{array}$ & $\begin{array}{l}37 \\
30 \\
48 \\
\end{array}$ & $2-4$ & scarcely visible & yes & flattened & rare & Acute $\left(40-52^{\circ}\right)$ & sheet-like & Multiserial sbt 2 & \\
\hline $\begin{array}{l}\text { Mean } \\
\text { Min } \\
\text { Max }\end{array}$ & СТA-61 & MUSM 2902 & ? & 2.7 & $\begin{array}{l}173 \\
172 \\
173 \\
\end{array}$ & $\begin{array}{l}18 \\
15 \\
21\end{array}$ & $\begin{array}{l}78 \\
74 \\
79\end{array}$ & $\begin{array}{l}83 \\
71 \\
88\end{array}$ & $\begin{array}{l}23 \\
15 \\
34 \\
\end{array}$ & 3-5 & well marked & no & round / flattened & very frequent & $\begin{array}{l}\text { Parallel to acute } \\
\qquad\left(0-10^{\circ}\right)\end{array}$ & $\begin{array}{l}\text { sheath-like / sheet- } \\
\text { like }\end{array}$ & Multiserial sbt 1-(2) & \\
\hline $\begin{array}{l}\text { Mean } \\
\text { Min } \\
\text { Max }\end{array}$ & СТA-61 & MUSM 2903 & $\begin{array}{l}\text { lower } \\
\text { right }\end{array}$ & 2.5 & $\begin{array}{l}156 \\
153 \\
160 \\
\end{array}$ & $\begin{array}{l}21 \\
19 \\
22 \\
\end{array}$ & $\begin{array}{l}78 \\
75 \\
81 \\
\end{array}$ & $\begin{array}{l}83 \\
69 \\
90 \\
\end{array}$ & $\begin{array}{l}40 \\
31 \\
46 \\
\end{array}$ & $3-4$ & well marked & yes & round / flattened & frequent & $\begin{array}{c}\text { Acute to rectangular } \\
\left(50-85^{\circ}\right)\end{array}$ & $\begin{array}{l}\text { sheet-like/ } \\
\text { interrow sheet-like }\end{array}$ & Multiserial sbt 2-3 & Fig. $2 c-d$ \\
\hline $\begin{array}{l}\text { Mean } \\
\text { Min } \\
\text { Max }\end{array}$ & СТA-61 & MUSM 2904 & lower & 2.3 & $\begin{array}{l}139 \\
137 \\
142 \\
\end{array}$ & $\begin{array}{l}22 \\
20 \\
24 \\
\end{array}$ & $\begin{array}{l}79 \\
78 \\
82 \\
\end{array}$ & $\begin{array}{l}73 \\
35 \\
89 \\
\end{array}$ & $\begin{array}{l}37 \\
28 \\
46 \\
\end{array}$ & 3-4 & well marked & yes & flattened & rare & Acute $\left(30-40^{\circ}\right)$ & sheet-like & Multiserial sbt 2 & \\
\hline $\begin{array}{l}\text { Mean } \\
\text { Min } \\
\text { Max }\end{array}$ & СТA-61 & MUSM 2905 & $\begin{array}{c}\text { lower } \\
\text { left }\end{array}$ & 1.8 & $\begin{array}{l}284 \\
281 \\
289 \\
\end{array}$ & $\begin{array}{l}15 \\
14 \\
16 \\
\end{array}$ & $\begin{array}{l}84 \\
82 \\
86 \\
\end{array}$ & $\begin{array}{l}80 \\
68 \\
89 \\
\end{array}$ & $\begin{array}{l}37 \\
33 \\
41 \\
\end{array}$ & $3-4$ & well marked & yes & flattened & rare & Acute $\left(45-60^{\circ}\right)$ & sheet-like & Multiserial sbt 2 & \\
\hline $\begin{array}{l}\text { Mean } \\
\text { Min } \\
\text { Max }\end{array}$ & CTA-61 & MUSM 2906 & $\begin{array}{l}\text { upper } \\
\text { right }\end{array}$ & 1.1 & $\begin{array}{l}151 \\
149 \\
153 \\
\end{array}$ & $\begin{array}{l}17 \\
15 \\
21 \\
\end{array}$ & $\begin{array}{l}81 \\
77 \\
84 \\
\end{array}$ & $\begin{array}{l}76 \\
59 \\
89 \\
\end{array}$ & $\begin{array}{l}32 \\
27 \\
36 \\
\end{array}$ & $3-4$ & well marked & no & flattened & frequent & Acute $\left(33-60^{\circ}\right)$ & sheet-like & Multiserial sbt 2 & \\
\hline $\begin{array}{l}\text { Mean } \\
\text { Min } \\
\text { Max }\end{array}$ & СТA-61 & MUSM 2907 & ? & 0.8 & $\begin{array}{l}187 \\
181 \\
195 \\
\end{array}$ & $\begin{array}{l}18 \\
17 \\
18 \\
\end{array}$ & $\begin{array}{l}80 \\
78 \\
82 \\
\end{array}$ & $\begin{array}{l}57 \\
46 \\
75 \\
\end{array}$ & $\begin{array}{l}27 \\
18 \\
37 \\
\end{array}$ & $2-4$ & well marked & $\begin{array}{c}\text { very } \\
\text { frequent }\end{array}$ & flattened & no & Acute $\left(27-40^{\circ}\right)$ & sheet-like & Multiserial sbt 2 & \\
\hline
\end{tabular}




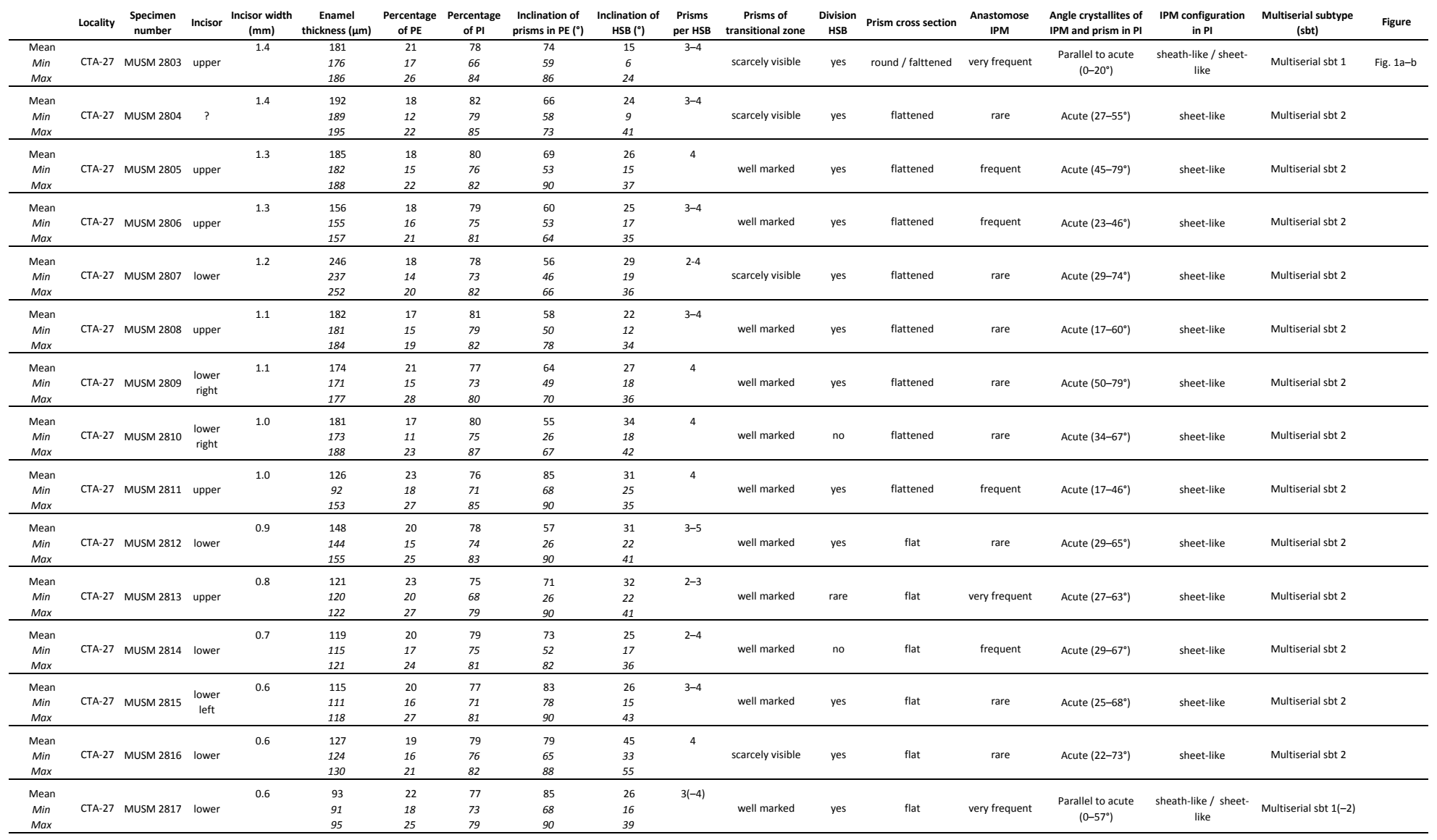




\begin{tabular}{|c|c|c|c|c|c|c|c|c|c|c|c|c|c|c|c|c|c|c|}
\hline & Locality & $\begin{array}{l}\text { Specimen } \\
\text { number }\end{array}$ & Incisor & $\begin{array}{c}\text { Incisor width } \\
(\mathrm{mm})\end{array}$ & $\begin{array}{c}\text { Enamel thickness } \\
(\mu \mathrm{m})\end{array}$ & Percentage of $\mathrm{PE}$ & $\begin{array}{l}\text { Percentage } \\
\text { of PI }\end{array}$ & $\begin{array}{l}\text { Inclination of prisms } \\
\text { in PE }\left(0^{\circ}\right)\end{array}$ & $\begin{array}{c}\text { Inclination of HSB } \\
\left({ }^{\circ}\right)\end{array}$ & $\begin{array}{l}\text { Prisms per } \\
\text { HSB }\end{array}$ & $\begin{array}{l}\text { Prisms of transitional } \\
\text { zone }\end{array}$ & $\begin{array}{c}\text { Division } \\
\text { HSB }\end{array}$ & $\begin{array}{l}\text { Prism cross } \\
\text { section }\end{array}$ & Anastomose IPM & $\begin{array}{l}\text { Angle crystallites of IPM and } \\
\text { prism in PI }\end{array}$ & IPM configuration in P1 & Multiserial subtype (sbt) & Figure \\
\hline $\begin{array}{l}\text { Mean } \\
\text { Min } \\
\text { Mox } \\
\end{array}$ & TAR-01 & MUSM 3342 & lower & 2.6 & $\begin{array}{l}152 \\
150 \\
153 \\
\end{array}$ & $\begin{array}{l}13 \\
12 \\
14 \\
\end{array}$ & $\begin{array}{l}79 \\
74 \\
81 \\
\end{array}$ & $\begin{array}{l}71 \\
63 \\
76 \\
\end{array}$ & $\begin{array}{l}22 \\
20 \\
26 \\
\end{array}$ & $(3)-5$ & well marked & no & $\begin{array}{l}\text { round / } \\
\text { falttened }\end{array}$ & rare & Acute $\left(29-58^{\circ}\right)$ & sheet-like & Multiserial sbt 2 & \\
\hline $\begin{array}{l}\text { Mean } \\
\text { Min } \\
\text { Max }\end{array}$ & TAR-01 & MUSM 3343 & lower & 1.8 & $\begin{array}{l}301 \\
284 \\
320\end{array}$ & $\begin{array}{l}14 \\
11 \\
16\end{array}$ & $\begin{array}{c}136 \\
79 \\
199\end{array}$ & $\begin{array}{l}57 \\
51 \\
62\end{array}$ & $\begin{array}{l}29 \\
27 \\
33 \\
\end{array}$ & $4-5$ & well marked & yes & flattened & rare & $\begin{array}{l}\text { Acute to rectangular } \\
\left(59-85^{\circ}\right)\end{array}$ & $\begin{array}{l}\text { sheet-like / interrow sheet- } \\
\text { like }\end{array}$ & Multiserial sbt (2)-3 & \\
\hline $\begin{array}{l}\text { Mean } \\
\text { Min } \\
\text { Max } \\
\end{array}$ & TAR-01 & MUSM 3344 & upper & 1.5 & $\begin{array}{l}171 \\
167 \\
179 \\
\end{array}$ & $\begin{array}{l}18 \\
15 \\
21 \\
\end{array}$ & $\begin{array}{l}80 \\
76 \\
85 \\
\end{array}$ & $\begin{array}{l}62 \\
50 \\
69 \\
\end{array}$ & $\begin{array}{l}23 \\
15 \\
29 \\
\end{array}$ & $3-4$ & well marked & yes & $\begin{array}{c}\text { oval/ } \\
\text { falttened }\end{array}$ & very frequent & Parallel to acute $\left(0-40^{\circ}\right)$ & sheet-like / sheath-like & Multiserial sbt 1-2 & \\
\hline $\begin{array}{l}\text { Mean } \\
\text { Min } \\
\text { Max }\end{array}$ & TAR-01 & MUSM 3345 & $\begin{array}{c}\text { lower } \\
\text { left }\end{array}$ & 1.3 & $\begin{array}{l}176 \\
172 \\
182 \\
\end{array}$ & $\begin{array}{l}14 \\
11 \\
17 \\
\end{array}$ & $\begin{array}{l}84 \\
80 \\
88 \\
\end{array}$ & $\begin{array}{l}66 \\
60 \\
72 \\
\end{array}$ & $\begin{array}{l}17 \\
4 \\
37 \\
\end{array}$ & $3-5$ & well marked & no & flattened & rare & Acute $\left(14-52^{\circ}\right)$ & sheet-like & Multiserial sbt 2 & \\
\hline $\begin{array}{l}\text { Mean } \\
\text { Min } \\
\text { Max }\end{array}$ & TAR-01 & MUSM 3346 & $\begin{array}{l}\text { upper } \\
\text { right }\end{array}$ & 1.3 & $\begin{array}{l}224 \\
212 \\
233\end{array}$ & $\begin{array}{l}12 \\
11 \\
14\end{array}$ & $\begin{array}{l}83 \\
79 \\
86 \\
\end{array}$ & $\begin{array}{l}87 \\
81 \\
90\end{array}$ & $\begin{array}{l}34 \\
16 \\
40\end{array}$ & 3-4 & well marked & yes & flattened & rare & Rectangular $\left(74-89^{\circ}\right)$ & interrow sheet-like & Multiserial sbt 3 & Fig. 3a-b \\
\hline $\begin{array}{l}\text { Mean } \\
\text { Min } \\
\text { Max } \\
\end{array}$ & TAR-01 & MUSM 3347 & upper & 1.3 & $\begin{array}{l}140 \\
139 \\
142 \\
\end{array}$ & $\begin{array}{l}19 \\
17 \\
21 \\
\end{array}$ & $\begin{array}{l}80 \\
78 \\
84 \\
\end{array}$ & $\begin{array}{l}74 \\
69 \\
77 \\
\end{array}$ & $\begin{array}{l}40 \\
29 \\
48 \\
\end{array}$ & 3-4 & well marked & yes & $\begin{array}{c}\text { round/ } \\
\text { falttened }\end{array}$ & rare & Acute $\left(19-59^{\circ}\right)$ & sheet-like & Multiserial sbt 2 & \\
\hline $\begin{array}{l}\text { Mean } \\
\text { Min } \\
\text { Mox } \\
\end{array}$ & TAR-01 & MUSM 3348 & $\begin{array}{l}\text { upper } \\
\text { left }\end{array}$ & 1.2 & $\begin{array}{l}133 \\
131 \\
133 \\
\end{array}$ & $\begin{array}{l}16 \\
14 \\
17 \\
\end{array}$ & $\begin{array}{l}81 \\
78 \\
83 \\
\end{array}$ & $\begin{array}{l}67 \\
58 \\
74 \\
\end{array}$ & $\begin{array}{l}34 \\
22 \\
42\end{array}$ & $2-3$ & well marked & yes & flattened & no & $\begin{array}{l}\text { Acute to rectangular } \\
\left(70-84^{\circ}\right)\end{array}$ & $\begin{array}{l}\text { sheet-like / interrow sheet- } \\
\text { like }\end{array}$ & Multiserial sbt 2-3 & \\
\hline $\begin{array}{l}\text { Mean } \\
\text { Min } \\
\text { Max } \\
\end{array}$ & TAR-01 & MUSM 3349 & lower & 1 & $\begin{array}{l}215 \\
209 \\
218\end{array}$ & $\begin{array}{l}15 \\
13 \\
18 \\
\end{array}$ & $\begin{array}{l}85 \\
82 \\
87 \\
\end{array}$ & $\begin{array}{l}88 \\
85 \\
90 \\
\end{array}$ & $\begin{array}{l}37 \\
28 \\
43 \\
\end{array}$ & 3-4 & scarcely visible & yes & flattened & no & Rectangular $\left(72-90^{\circ}\right)$ & interrow sheet-like & Multiserial sbt 3 & \\
\hline $\begin{array}{l}\text { Mean } \\
\text { Min } \\
\text { Max } \\
\end{array}$ & TAR-01 & MUSM 3350 & $\begin{array}{l}\text { upper } \\
\text { left }\end{array}$ & 0.9 & $\begin{array}{l}133 \\
131 \\
134\end{array}$ & $\begin{array}{l}22 \\
18 \\
25 \\
\end{array}$ & $\begin{array}{l}78 \\
73 \\
82\end{array}$ & $\begin{array}{l}63 \\
56 \\
72\end{array}$ & $\begin{array}{l}34 \\
24 \\
45\end{array}$ & $3-4$ & well marked & yes & flattened & frequent & Acute $\left(18-45^{\circ}\right)$ & sheet-like & Multiserial sbt 2 & \\
\hline $\begin{array}{l}\text { Mean } \\
\text { Min } \\
\text { Max } \\
\end{array}$ & TAR-01 & MUSM 3351 & $\begin{array}{l}\text { upper } \\
\text { right }\end{array}$ & 0.8 & $\begin{array}{l}111 \\
110 \\
112 \\
\end{array}$ & $\begin{array}{l}23 \\
17 \\
26 \\
\end{array}$ & $\begin{array}{l}77 \\
74 \\
79 \\
\end{array}$ & $\begin{array}{l}83 \\
72 \\
89 \\
\end{array}$ & $\begin{array}{l}30 \\
24 \\
38 \\
\end{array}$ & $3-4$ & scarcely visible & yes & flattened & frequent & Acute $\left(28-47^{\circ}\right)$ & sheet-like & Multiserial sbt 2 & \\
\hline $\begin{array}{l}\text { Mean } \\
\text { Min } \\
\text { Max }\end{array}$ & TAR-01 & MUSM 3352 & $\begin{array}{l}\text { lower } \\
\text { right }\end{array}$ & 0.8 & $\begin{array}{l}106 \\
104 \\
107 \\
\end{array}$ & $\begin{array}{l}25 \\
19 \\
31 \\
\end{array}$ & $\begin{array}{l}72 \\
68 \\
74 \\
\end{array}$ & $\begin{array}{l}69 \\
64 \\
80 \\
\end{array}$ & $\begin{array}{l}46 \\
36 \\
57 \\
\end{array}$ & $3-4$ & well marked & no? & $\begin{array}{l}\text { round/ } \\
\text { falttened }\end{array}$ & no & Rectangular $\left(71-90^{\circ}\right)$ & interrow sheet-like & Multiserial sbt 3 & Fig. $3 c-d$ \\
\hline $\begin{array}{l}\text { Mean } \\
\text { Min } \\
\text { Max }\end{array}$ & TAR-01 & MUSM 3353 & upper & 0.6 & $\begin{array}{l}104 \\
101 \\
105\end{array}$ & $\begin{array}{l}22 \\
18 \\
29\end{array}$ & $\begin{array}{l}73 \\
67 \\
76\end{array}$ & $\begin{array}{l}80 \\
74 \\
87\end{array}$ & $\begin{array}{l}24 \\
16 \\
38 \\
\end{array}$ & $3-4$ & well marked & yes & $\begin{array}{l}\text { round/ } \\
\text { falttened }\end{array}$ & frequent & Parallel to acute $\left(0-43^{\circ}\right)$ & sheet-like / sheath-like & Multiserial sbt (1)-2 & Fig. $1 c-d$ \\
\hline
\end{tabular}


Click here to access/download

\section{Supplemental Material Supple Info.pdf}

